\title{
Stratigraphy of Late Cenozoic sediments of the western Chukchi Sea: New results from shallow drilling and seismic-reflection profiling
}

\author{
E.A. Gusev a,*, I.A. Andreeva ${ }^{\text {a }}$, N.Y. Anikina ${ }^{\text {b }}$, S.A. Bondarenko a , L.G. Derevyanko ${ }^{\text {b }}$, A.G. Iosifidi ${ }^{\text {, }}$, \\ T.S. Klyuvitkina ${ }^{\mathrm{d}}$, I.V. Litvinenko ${ }^{\text {a }}$, V.I. Petrova ${ }^{\text {a }}$, E.I. Polyakova ${ }^{\mathrm{d}}$, V.V. Popov ${ }^{\mathrm{c}}$, A.Y. Stepanova ${ }^{\mathrm{e}}$ \\ ${ }^{a}$ VNIIOkeangeologia, St. Petersburg, Russia \\ b Mireco Mining Company, Syktyvkar, Russia \\ c All-Russian Oil Research and Geological Reconnaissance Institute (VNIGRI), St. Petersburg, Russia \\ d Lomonosov Moscow State University, Russia \\ e Paleontological Institute, Russian Academy of Sciences, Moscow, Russia
}

\section{A R T I C L E I N F O}

\section{Article history:}

Accepted 26 March 2009

Available online 3 May 2009

\section{Keywords:}

Chukchi Sea

Beringia

sediment stratigraphy

seismic stratigraphy

Pliocene

Quaternary

\begin{abstract}
A B S T R A C T
The Quaternary history of Beringia and of the Arctic-Pacific marine connection via the Bering Strait is poorly understood because of the fragmentary stratigraphic record from this region. We report new borehole and seismic-reflection data collected in 2006 in the southwestern Chukchi Sea. Sediment samples were analyzed for magnetic properties, grain size, heavy minerals, and biostratigraphic proxies (spores and pollen, foraminifers, ostracodes, diatoms, and aquatic palynomorphs). Two shallow boreholes drilled between the Chukotka Peninsula and the Wrangel Island recovered sediments of two principal stratigraphic units with a distinct unconformity between them. Based on predominantly reverse paleomagnetic polarity of the lower unit and pollen spectra indicative of forested coasts and climate warmer than present, the age of this unit is estimated as Pliocene to early Pleistocene (broadly between ca. 5 and $2 \mathrm{Ma}$ ). Attendant sedimentary environments were likely alluvial to nearshore marine. These deposits can be correlated to the seismic unit infilling valleys incised into sedimentary bedrock across much of the study area, and possibly deposited during a transgression following the opening of the Bering Strait. The upper unit from both boreholes contains Holocene ${ }^{14} \mathrm{C}$ ages and is clearly related to the last, postglacial transgression. Holocene sediments in Borehole 2 indicate fast deposition at the early stages of flooding (between ca. 11 and $9 \mathrm{ka}$ ) to very low deposition, possibly related to expansive sea ice. Closer to shore, deposition at Borehole 1 resumed much later (ca. $2 \mathrm{ka}$ ), likely due to a change in the pattern of coastal erosional processes and/or the demise of a landbridge between the Chukotka Peninsula and the Wrangel Island inferred from studies on mammoth distribution.
\end{abstract}

(c) 2009 Elsevier B.V. All rights reserved.

\section{Introduction}

The shallow Chukchi Sea shelf (Fig. 1), together with the Bering Strait, was repeatedly subaerially exposed during the Late Cenozoic sea level drops, forming the Beringia landmass. The timing of openings and closures of the Bering Strait is essential for any reconstruction of the Late Cenozoic sedimentation and paleoceanographic history in the Pacific sector of the Arctic. Based on paleontological evidence, the waters of the North Pacific first entered the Arctic Ocean in the Late Miocene to Early Pliocene (Marincovich and Gladenkov, 2001; Gladenkov and Gladenkov, 2004) or, by some suggestions, as early as the Middle Miocene (Polyakova, 1997, 1999). Since then, the Bering Strait and the Chukchi shelf experienced several marine regressions and transgressions related to either tectonic or glacio-eustatic processes (Brigham-Grette and Carter, 1992; Svitoch and Taldenkova,

\footnotetext{
* Corresponding author.

E-mail address: gus-evgeny@yandex.ru (E.A. Gusev).
}

1994). The most recent reopening of the Bering Strait and flooding of the Chukchi shelf occurred about 11-12 ka after the low sea-level stand related to the last glaciation (Elias et al., 1997a; Keigwin et al., 2006). Recently, a stratigraphic background was outlined for the CHIRP data from the eastern (American) part of the Chukchi Sea shelf comprising the potentially Pliocene to Quaternary deposits that infill the channels incised into the Cretaceous bedrock and are covered with a veneer of Holocene sediments (Keigwin et al., 2006; Hill et al., 2007). However, the age of these deposits was only tentatively determined because of insufficient core penetration below the sediments of the last marine transgression.

We present new data that shed light on the age and composition of Pliocene/Quaternary deposits on the Chukchi shelf (Fig. 2). Our survey was carried out in the southwestern (Russian) part of the Chukchi Sea in 2006. Survey methods included sparker and sonar profiling, bottom sampling with a box-corer and gravity corer, as well as shallow drilling down to $50 \mathrm{~m}$ enabled by a novel, portable drilling rig (Kalinichenko et al., 2001). This expedition resulted in $1500 \mathrm{~km}$ of sparker lines, a sidescan-sonar surveyed area, 100 surface-sediment 


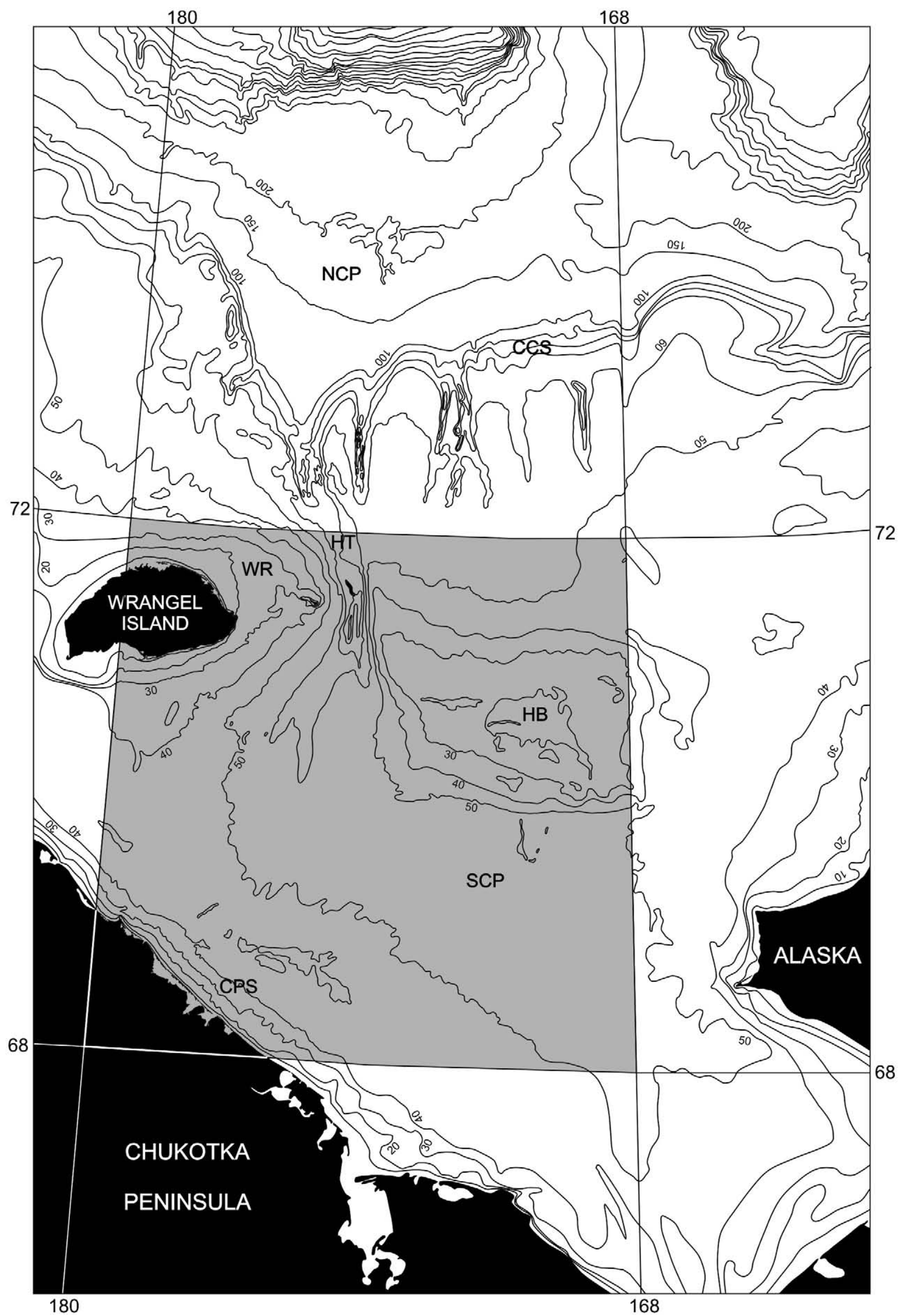



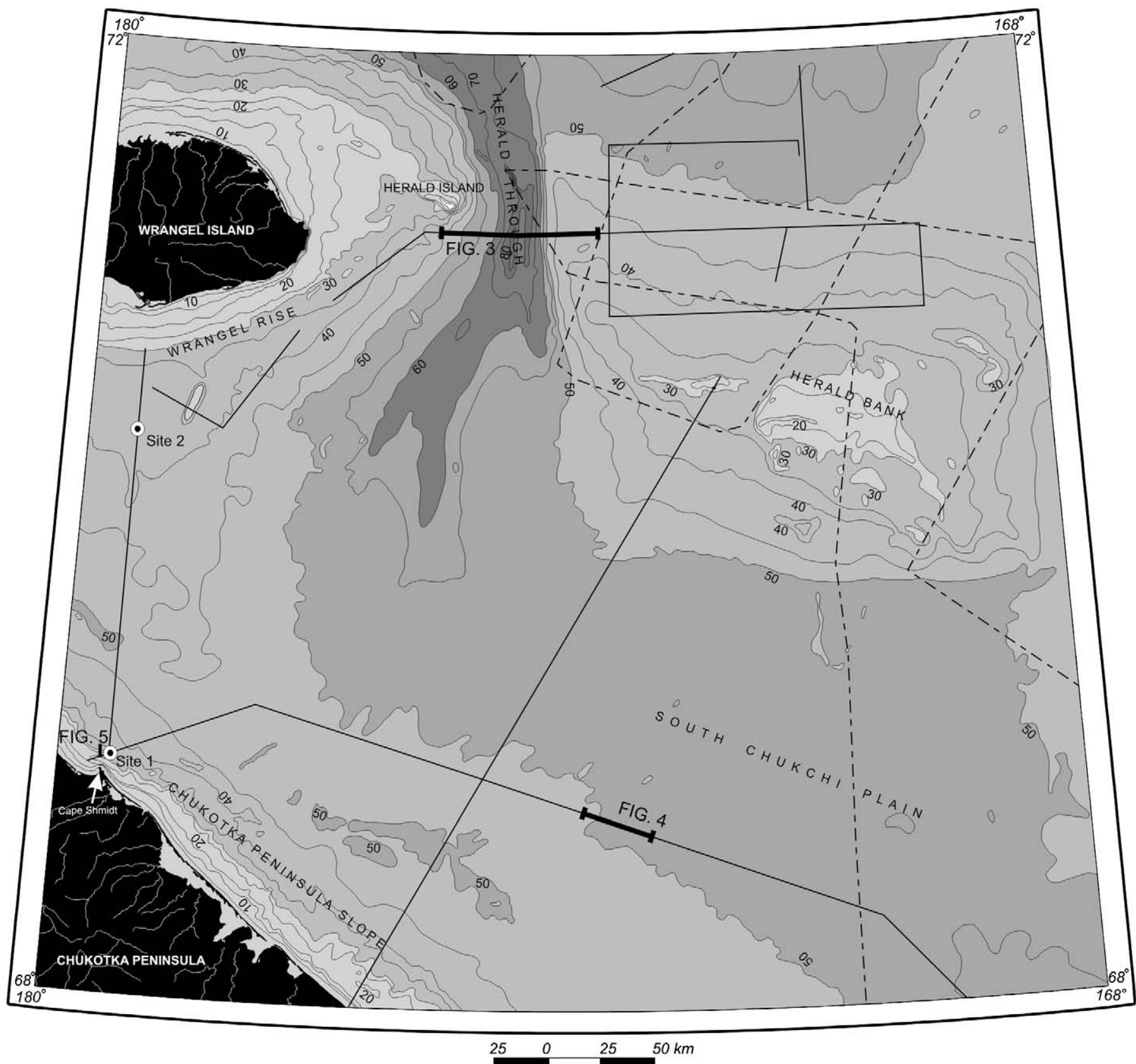

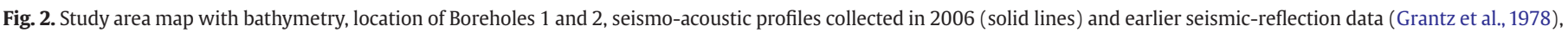

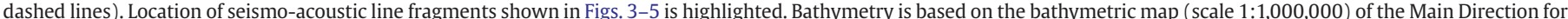

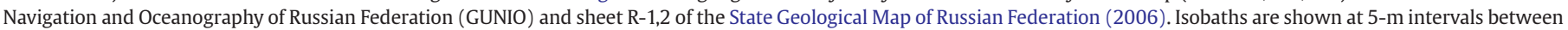
0 and $60 \mathrm{~m}$, and at 10-m intervals between 60 and $100 \mathrm{~m}$.

samples, 22 gravity cores, and three boreholes $(3.5 \mathrm{~m}, 5.5 \mathrm{~m}$, and $12 \mathrm{~m}$ long). Two boreholes with a complete recovery drilled between the Chukotka mainland and the Wrangel Island have been investigated in detail.

\section{Geological background}

The surveyed part of the Chukchi shelf (Fig. 1) was affected by Late Mesozoic and Caledonian tectonism. The Late Mesozoic folded basement in the shelf zone contains the South-Chukchi Basin with sediment thicknesses reaching $4 \mathrm{~km}$ (Vinogradov et al., 2006). The region of Caledonian folding includes the latitudinally-oriented North-Chukchi Basin with sediment fill up to 20-22 km thick (State Geological Map of Russian Federation, 2006). These two basins ranging in age and size are divided by the structural Herald Uplift (Herald Arc: Grantz et al., 1975; Thurston and Theiss, 1987; Miller et al., 2002). This uplift is expressed in bathymetry as the Herald Bank, whereas the adjacent basins correspond to sea-floor depressions.

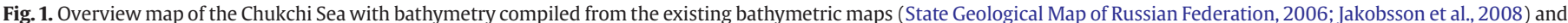

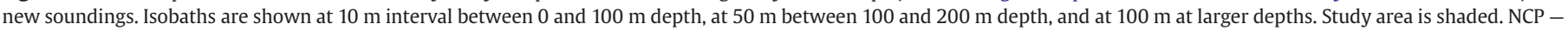

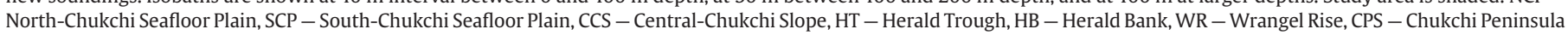
Submarine Slope. 
Table 1

Borehole location, water depth, and core length.

\begin{tabular}{|c|c|c|c|c|}
\hline Borehole \# & Latitude & Longitude & $\frac{\text { Water depth }}{(\mathrm{m})}$ & $\frac{\text { Core length }}{(\mathrm{m})}$ \\
\hline 1 & $69^{\circ} 53.0^{\prime} \mathrm{N}$ & $179^{\circ} 19.20^{\prime} \mathrm{W}$ & 37 & 5.5 \\
\hline 2 & $70^{\circ} 33.0^{\prime} \mathrm{N}$ & $179^{\circ} 23.72^{\prime} \mathrm{W}$ & 39 & 12 \\
\hline
\end{tabular}

The bottom topography of the Chukchi Sea shelf is generally level to gently inclined with several inferred paleo-shorelines. Based on bathymetric data, a submerged shorelines were inferred at modern depths of 9, 15, 18-22, 25-27, 30, 33-35, 40-45, and 50-55 m (Morozova et al., 1978; Morozova, 1985). Some of these shoreline identifications were later supported by seismo-acoustic studies (Pavlidis et al., 1981).

The upper part of the sedimentary cover on the Chukchi shelf was studied with sparker and boomer seismic reflection in the 1960-1980s (Creager and McManus, 1965; Grantz et al., 1978; Pavlidis et al., 1981; Phillips et al., 1988a) and then with CHIRP-sonar profiling in 2002 (Hill et al., 2007). These data provide a seismo-stratigraphic framework mostly for the eastern Chukchi Sea and partially covering the area of our study (Fig. 2). A number of sediment cores were raised from the bottom of the Chukchi Sea, but age-constrained sedimentary records have been available so far only for the eastern part of the shelf. The oldest strata recovered by piston coring are Late Pleistocene to Holocene sediments deposited during the last transgression and dating back to $\sim 14{ }^{14} \mathrm{C}$ ka (Creager and McManus, 1965; Keigwin et al., 2006; Hill et al., 2007). In the western part of the shelf, the Holocene deposits were subdivided by means of foraminiferal analysis into pre-Boreal, Boreal, Atlantic, sub-Boreal, and sub-Atlantic ecologic zones (Saidova, 1994). Similar results were achieved using diatom assemblages (Polyakova, 1989a,b,c, 1997, 1999). Vibra-cores used in the eastern part of the shelf recovered Upper Cretaceous deposits comprising the sedimentary bedrock (Phillips and Colgan, 1987; Phillips et al., 1988b) and deposits of uncertain age infilling valleys incised into this bedrock (Phillips et al., 1988a).
Shallow drilling that was carried out from ice in the nearshore zone in the western Chukchi Sea recovered more extensive Upper Cenozoic deposits than in the eastern part of the shelf (Puminov, 1981). Based on the analysis of palynomorphs, plant remnants, foraminifers, and diatoms, deposits underlying the Holocene unit were identified as Miocene to Pliocene or Pliocene to Upper Pleistocene. These deposits contain numerous shrub and tree pollen, moderate amounts of herbs, and minor numbers of spores, while the overlying Late Pleistocene to Holocene sediments are notably enriched in marine diatoms, while cooccurring spores and pollen indicate forested-tundra environments (Puminov, 1981).

\section{Materials and methods}

In this paper, we present new seismic-reflection profiles and sediment-core data from two boreholes along with a new bathymetric compilation for the study area (Fig. 2). Geophysical studies carried out in 2006 included (a) seismo-acoustic profiling with a 40-electrode sparker array with an operating frequency of $200-1200 \mathrm{~Hz}$ and charge energy of $2000 \mathrm{~J}$, and (b) a survey of selected sites by a side-scan sonar coupled with a hydro-acoustic sonar profiler, with operating frequencies of $115 \mathrm{kHz}$ and 7 to $20 \mathrm{kHz}$, respectively.

Shallow drilling was performed by a wireline device (Kalinichenko et al., 2001). Boreholes, 1 and 2 were investigated in detail (Fig. 2; Table 1). The cores were photographed and described, measured for magnetic susceptibility (Figs. 8 and 9), and sampled for various analyses. For paleomagnetic studies, 46 samples were taken from Borehole 1, and 114 samples from Borehole 2. Paleomagnetic analyses and processing of results were performed following the standard methodics (Kirschvink, 1980; Hramov, 1982; Kochegura, 1992). Magnetic cleaning of samples was achieved by stepwise thermal and alternating-field demagnetization. Samples with odd and even numbers were demagnetized by thermal cleaning and by alternating fields, respectively.

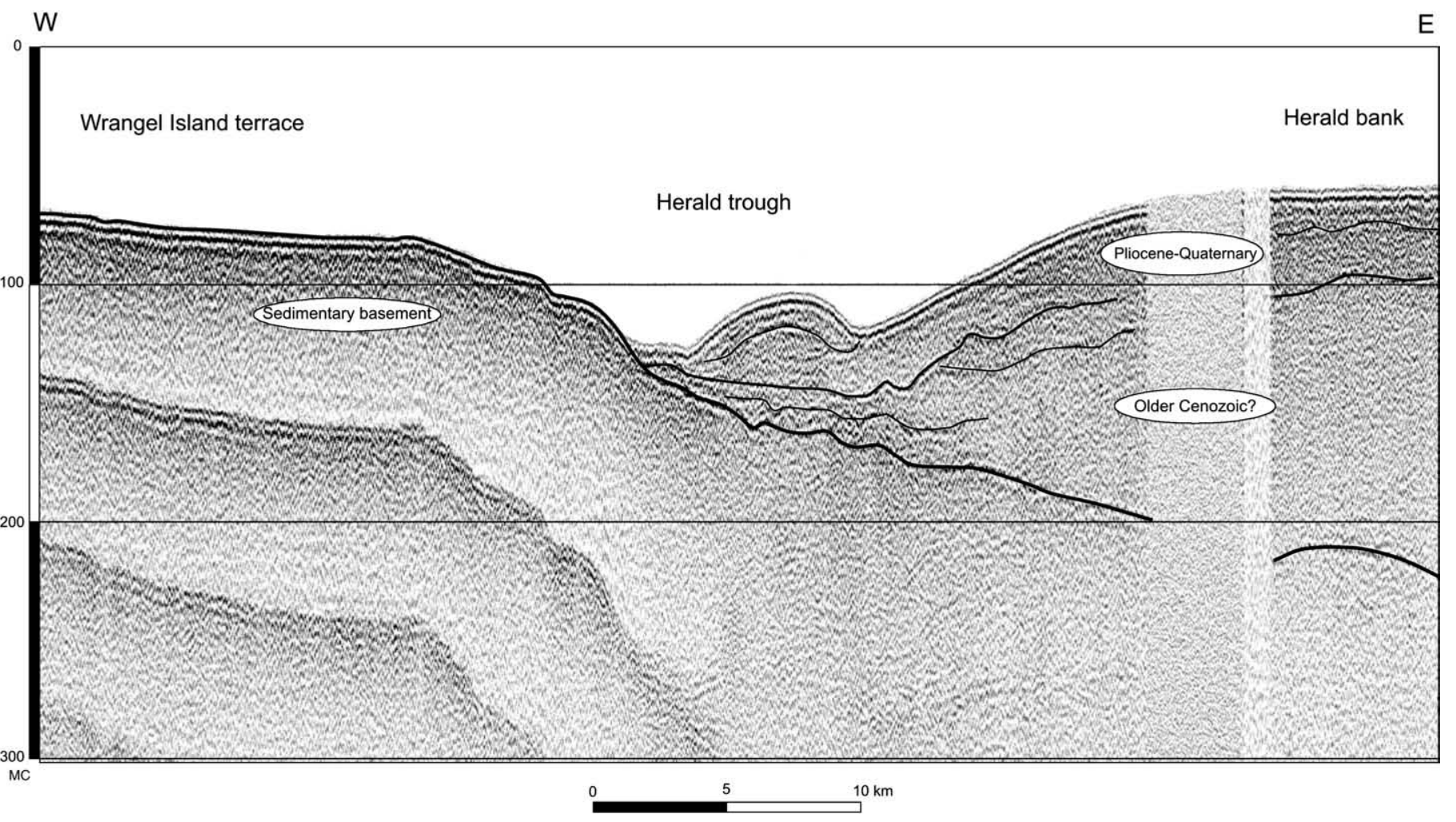

Fig. 3. Sparker profile across the Herald Trough (see Fig. 2 for location). 
Sediment cores were sampled at intervals of $10-50 \mathrm{~cm}$ for grainsize and heavy-mineral analyses and for the investigation of organic matter and biostratigraphic indicators - foraminifers, ostracodes, spores and pollen, diatoms, and aquatic palynomorphs. Mollusc shells were picked for ${ }^{14} \mathrm{C}$ age determination. Grain size was determined by sieving and pipette analysis. Heavy minerals were identified in the 50 $100 \mu \mathrm{m}$ size fraction mounted in an immersion under the petrographic polarization microscope (after separation of heavy and light subfractions at $2.9 \mathrm{~g} / \mathrm{cm}^{3}$ density). Organic matter was analyzed in samples from Borehole 2. The analytical procedure included determination of organic carbon and carbonate contents by a wet combustion method, extraction of bitumoids and determination of their group characteristics, chromatographic fractionation of bitumoids with the extraction of hydrocarbons, and GC-MS measurement of hydrocarbon biomarkers (alkanes, cyclanes, and arenes) on Hewlett Packard 6850/5973 GC-MS with a quadrupole mass-detector.

\section{Results}

\subsection{Seismic stratigraphy}

The compiled bathymetry shows a wide, gently sloping area in the outer part of the shelf at depths of 100-300 m (Fig. 1). The inner part of the shelf lying at depths less than $100 \mathrm{~m}$ is also characterized by level topography. The transition between the two areas represents a slope zone with a complex morphology cut by sub-longitudinal canyons up to $30 \mathrm{~m}$ deep.
Principle geological/morphological structures in the study area include the submarine part of the Chukotka Peninsula slope, the SouthChukchi Seafloor Plain, and the seafloor uplift in the area of Wrangel and Herald islands separated by the Herald Trough from the Herald Bank (Fig. 2). The thickness of the upper part of sedimentary cover at the shelf of the Chukchi Sea varies considerably. For example, a fragment of seismoacoustic profile presented in Fig. 3 shows that the sedimentary cover is virtually absent west of the Herald Trough, but is quite thick at the eastern edge of the profile. The western flank of the trough appears to be affected by erosional or non-depositional processes, while the eastern flank contains an accumulative sedimentary lens.

The comparison of earlier seismo-acoustic and borehole data (Grantz et al., 1978; Pavlidis et al., 1981; Hill et al., 2007) with our new data indicates that western and eastern parts of the Chukchi Sea shelf have somewhat different histories of sedimentation. In the eastern part of the shelf, young (Pliocene and/or Quaternary) sediments infill several generations of deep, narrow valleys incised in dislocated or monoclinally bedded Cretaceous strata (Phillips et al., 1988a,b; Hill et al., 2007). In the western part, young sediments also infill depressions in the eroded surface of Cretaceous and/or Cenozoic strata, however, the size of these depressions is commonly greater than further east (tens of kilometers), and the underlying bedrock is more subhorizontally bedded (e.g., Fig. 4). The largest feature is the sedimentary basin south of the Herald Bank, which occupies the entire South-Chukchi Seafloor Plain and narrows southward toward the Kotzebue Sound Gulf, where it is known as the Hope Valley (Keigwin et al., 2006). The seismic unit immediately overlying the main erosional surface in this

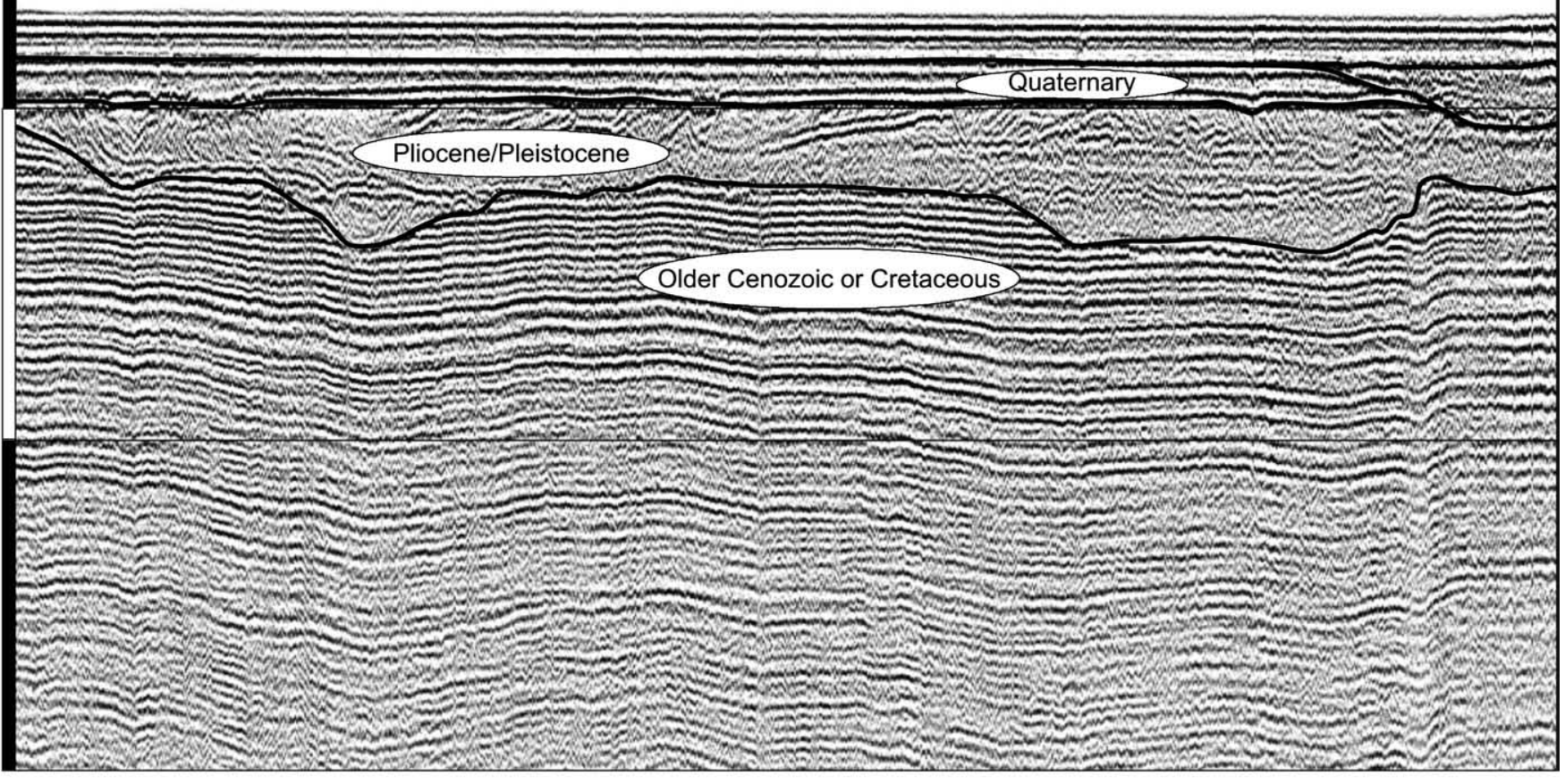

MC

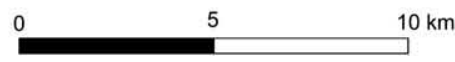

Fig. 4. Sparker profile from the South-Chukchi Seafloor Plain (see Fig. 2 for location), 


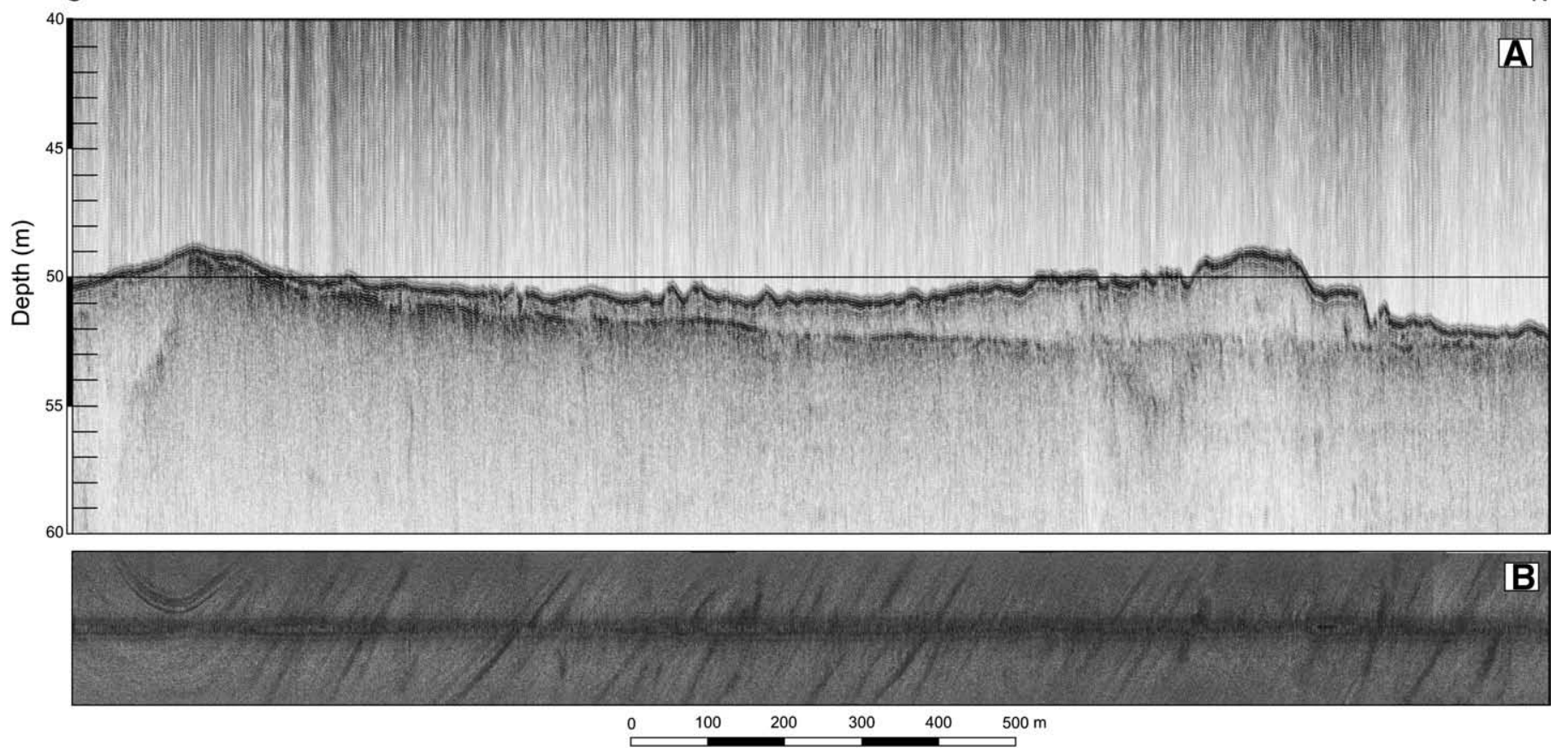

Fig. 5. Penetration and a side-scan sonar records of a profile near Cape Schmidt, west of Borehole 1 (see Fig. 2 for location). Side-scan swath is 140 m.

area, and partially recovered in our boreholes, contains inclined, unevenly spaces beds (middle unit on Fig. 4). It is unconformably overlain by mostly horizontally layered sediments identified in other parts of the shelf as deposits of the last sea-level rise (Phillips et al., 1988a; Keigwin et al., 2006; Hill et al., 2007).

A small polygon was covered by side-scan and penetrating sonar survey west of Borehole 1 (Figs. 2 and 5). Side-scan sonar images show that sea floor in this area is covered by long, mostly subdued linear morphological features parallel to the shore, as well as diversely oriented and smaller but fresher-looking scours (Fig. 5A). Sonar profiling indicates that the long, linear features correspond to accumulative sediment lenses (Fig. 5B). Such features could be sand bars formed by sediment transport with along-shore currents. The surface of these bedforms is covered by gouges (scours) similar to erosional markings formed by icebergs or sea-ice ridges. The latter have been identified in other shallow areas of the Chukchi Sea shelf (Rex, 1955; Phillips and Reiss, 1985; Phillips et al., 1988a), and we consider ice-ridge erosion as the most likely cause of gouging in our study area.

\subsection{Lithostratigraphy}

The sedimentary stratigraphy obtained from boreholes can be divided into two major units by a suite of lithologic and biostratigraphic data (Figs. 6 and 7). Sonar profiler records at the borehole sites show that these units are separated by an erosional unconformity and can be correlated to the upper and middle seismic units on seismo-acoustic records across the study area (e.g., Fig. 4).

In Borehole 1 collected near the Chukotka coast, the lower lithostratigraphic unit (Unit II; below 2.4-m core depth) is composed of sands with lenses of finer-grained sediment and gravelly/pebbly bed at the core bottom (Fig. 6). On the sonar profiler record the corresponding seismic unit looks opaque, with no internal layering discernible. The upper lithostratigraphic unit (Unit I) is generally composed of much finer sediment (silty to clayey mud) with a sandy/ gravelly layer at the bottom and some scattered coarse grains. The upper unit can be subdivided into three subunits, with the middle subunit containing the highest amount of coarse sand and gravel. The sea floor at the Borehole 1 site is heavily gouged, as illustrated by both penetration and side-scan images (Figs. 5 and 6). The sonar record west of the drill site (Fig. 5) shows also the accumulative sediment body (sand bar), which could be related to the upper unit in Borehole 1.

Borehole 2 contains overall finer-grained sediments, which enabled a deeper penetration (Fig. 7). The lower lithostratigraphic unit in Borehole 2 (below 7-m core depth) comprises interstratified, $\sim 1$-m-thick beds of muddy sands and sandy/silty muds with lenses of gravel and plant fragments. The upper unit consists of silty/clayey muds and can be subdivided into three subunits, where the lower subunit contains a gravelly bed at the bottom, and the upper subunit is most fine grained and contains numerous mollusc shells. On the sonar profiler record across the borehole site the lower lithological unit shows inclined bedding and can be correlated to the middle seismic unit on records across the South Chukchi Plain (Fig. 4), which infills the oldest generation of valleys in the eroded surface of Cretaceous and/or Cenozoic strata. The acoustic signature for the upper unit grades upwards from the inclined to subhorizontal bedding, with distinct horizontal stratification on top (Fig. 7).

\subsection{Radiocarbon dating}

Radiocarbon dating was performed on shells of mollusks Margarites, Astarte, Portlandia, and Cylichna sp. or shell detritus, collected from the upper lithostratigraphic unit (Table 2; Figs. 6 and 7). For the reservoir correction we used dR of 460 years as demonstrated for shallow water depths off the northern and western coasts of Alaska (McNeely et al., 2006). In each core ages form an orderly succession suggesting a late

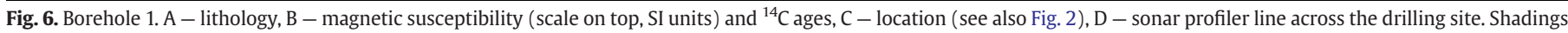
in panel B show subunits within Unit I. 
A
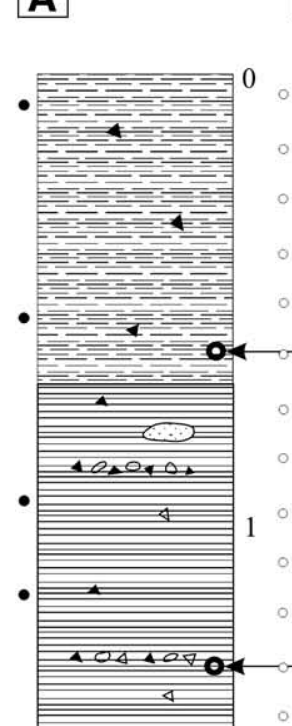

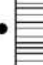

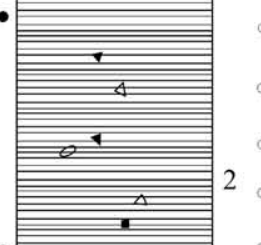

-

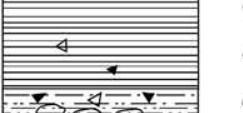

-

-

@

$\Delta 0 \Delta$

$0 ; 0 ;: 0$

- $\Delta \Delta \Delta: \Delta$

2
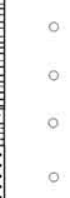

B

$\begin{array}{lllll}100 & 200 & 300 & 400 & 500\end{array}$

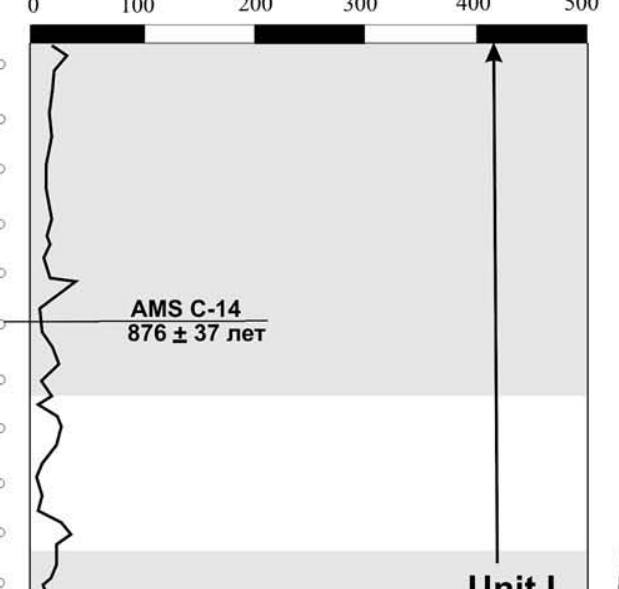

AMS C-14

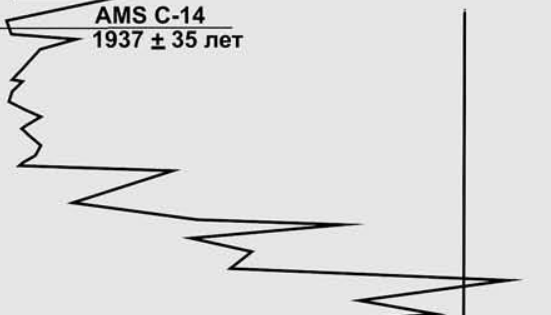

。

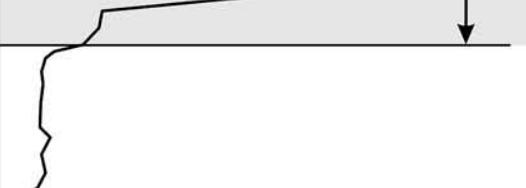

C
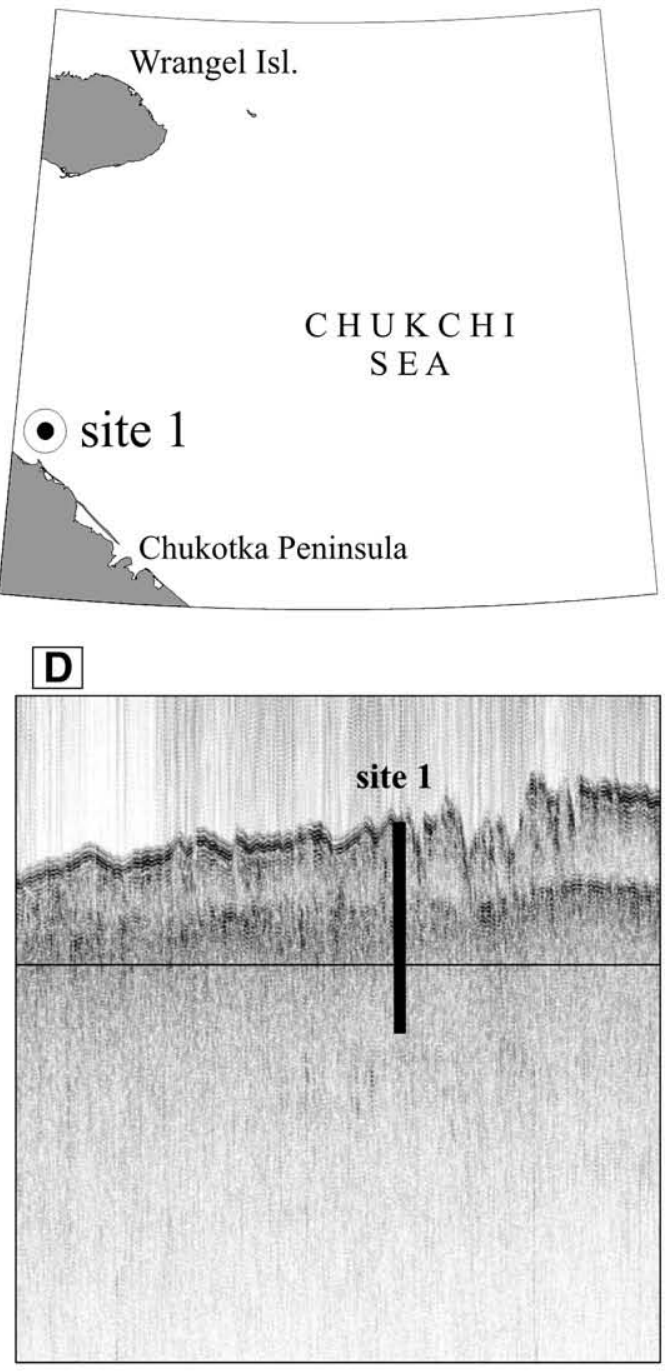

LE G E N D

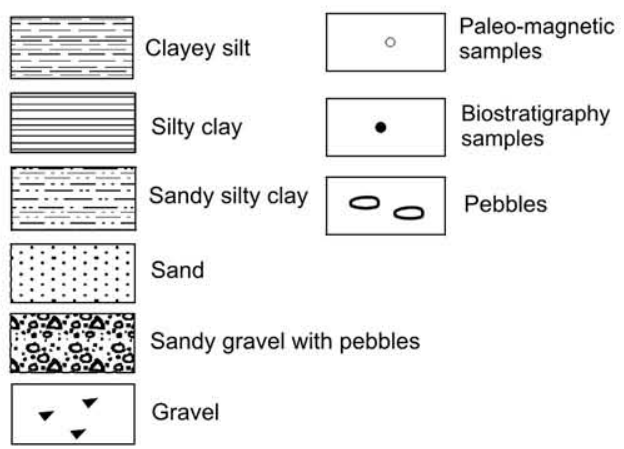


$\mathbf{A}$

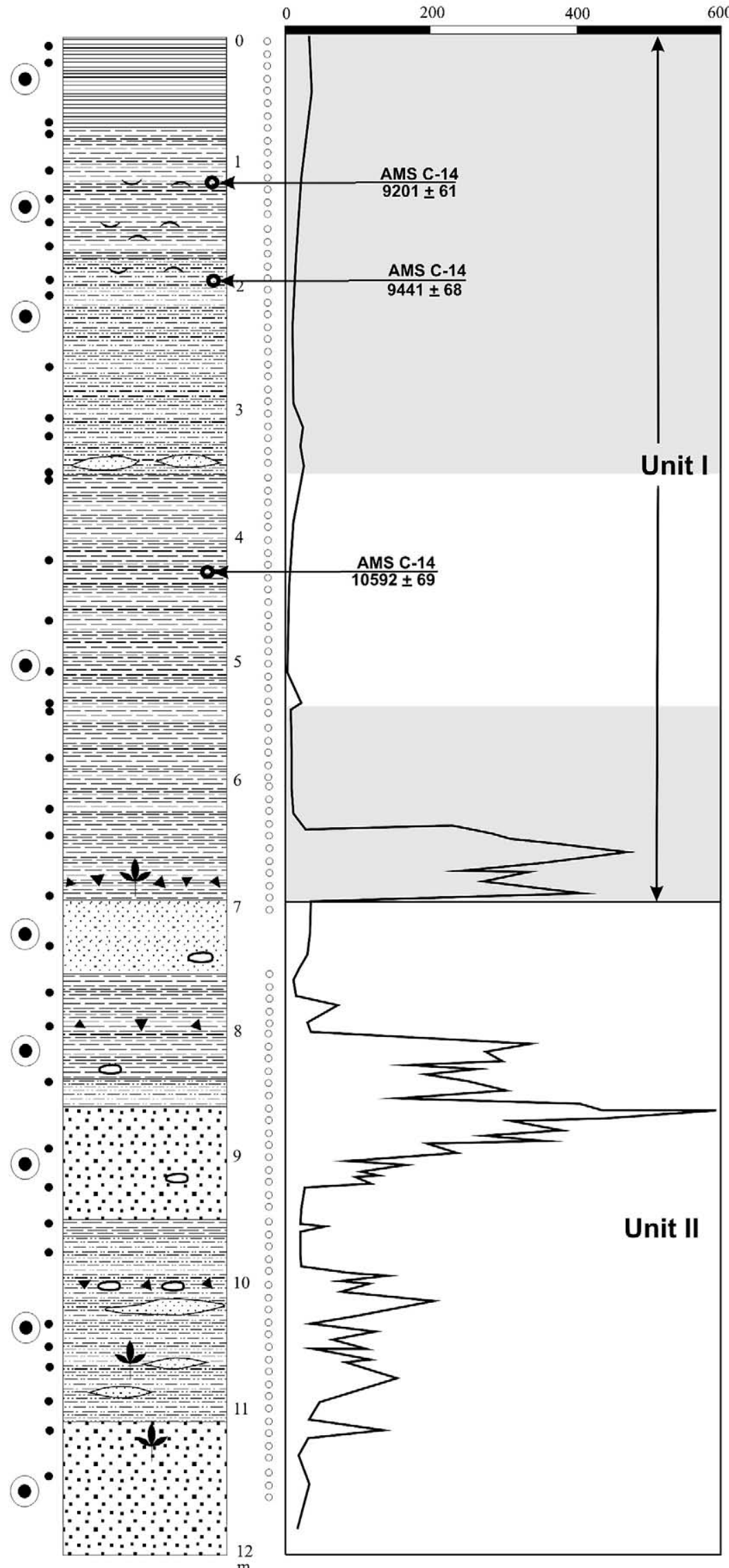

C
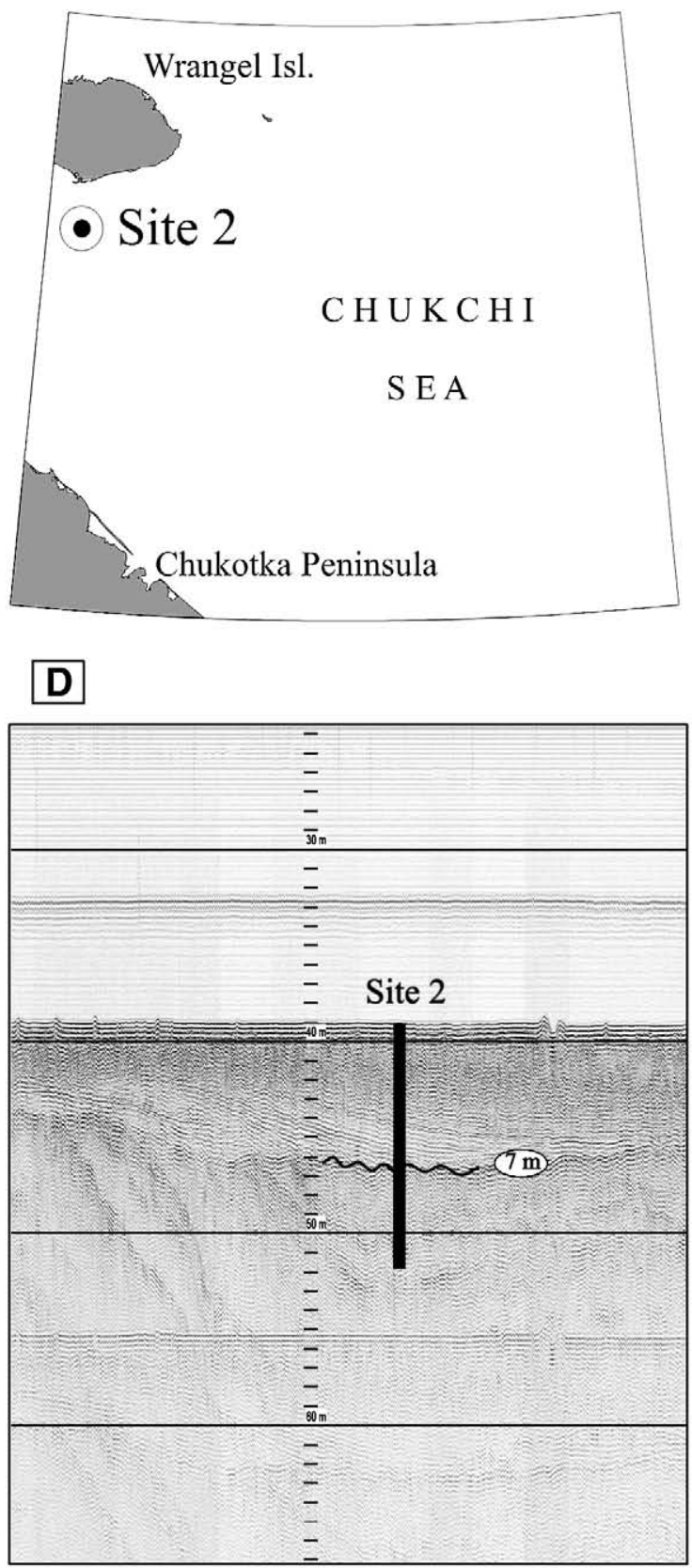

L E G E N D
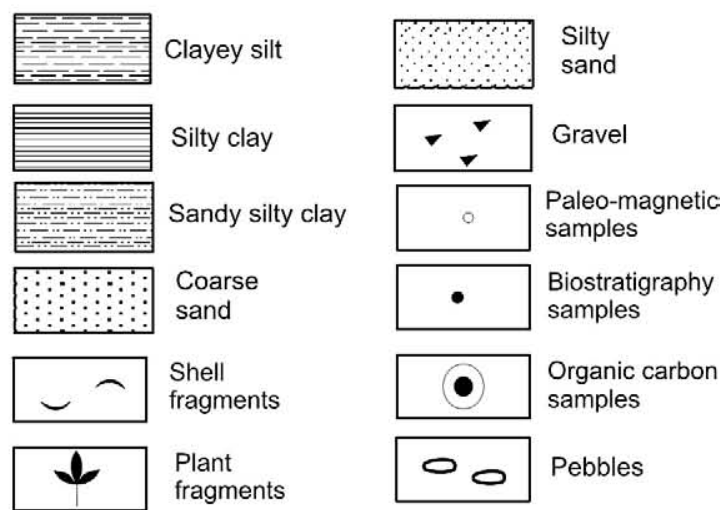

Shell fragments

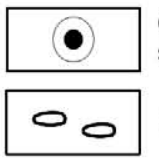

Organic carbon samples

Plant fragments Pebbles 
Table 2

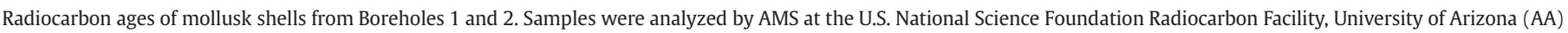
and calibrated using CALIB v 5.0.2 (http://calib.qub.ac.uk/calib).

\begin{tabular}{|c|c|c|c|c|c|c|c|c|c|c|c|c|c|}
\hline Core \# & $\frac{\text { Core depth }}{(\mathrm{cm})}$ & Material & $\frac{\text { Weight }}{(\mathrm{mg})}$ & AA & Suite & Run date & $d^{13} \mathrm{C}$ value & $F\left(d^{13} C\right)$ & $\pm d F\left(d^{13} C\right)$ & ${ }^{14} \mathrm{C}$ age $\mathrm{BP}$ & $\pm{ }^{14} \mathrm{C}$ age & $\begin{array}{l}\text { Cal. age } \\
\text { (res.corr 460) }\end{array}$ & $1 \mathrm{std}$ dev \\
\hline 1 & $50-60$ & Margarites & 525 & AA75303 & 6 of 8 & N09-23-07 & 2.5 & 0.8966 & 0.0042 & 876 & 37 & Too young & \\
\hline 1 & $116-121$ & Shell detritus & 7 & AA75302 & 5 of 8 & N09-12-07 & 1.9 & 0.7858 & 0.0035 & 1937 & 35 & 975 & 34 \\
\hline 2 & $121-128$ & Astarte (?) fragment & 320 & AA75301 & 4 of 8 & N09-23-07 & 1.9 & 0.3181 & 0.0025 & 9201 & 61 & 9367 & 85 \\
\hline 2 & 191-198 & Portlandia & 70 & AA75300 & 3 of 8 & N09-23-07 & -0.7 & 0.3087 & 0.0027 & 9441 & 68 & 9542 & 42 \\
\hline 2 & $428-433$ & Cylichna (?) fragment & 9 & AA75299 & 2 of 8 & N09-23-07 & -4.2 & 0.2675 & 0.0023 & 10,592 & 69 & 11,166 & 77 \\
\hline
\end{tabular}

Holocene age (less than $1 \mathrm{cal}$. ka) for the upper half of the upper unit in Borehole 1, and an early Holocene age (between 9 and $11 \mathrm{cal}$. ka) for most of the upper unit in Borehole 2.

\subsubsection{Paleomagnetic studies}

Predominantly normal magnetizations are observed in the upper lithostratigraphic unit in both boreholes, except for a short interval between 0.3 and $0.8 \mathrm{~m}$ in Borehole 1 (Fig. 8). In contrast, sediments of the lower unit in both boreholes are predominantly reversely magnetized. A short interval of normal polarity within the lower unit occurs in the 7.7-8.6 m interval in Borehole 2 and near the top of the unit (ca. 2.5-3 m) in Borehole 1, with intermittent magnetization values extending down to ca. $4 \mathrm{~m}$ (Fig. 8).

Distribution of magnetic susceptibility in both cores shows prominent peaks near the bottom of the upper unit (Figs. 6 and 7). Apparently similar peaks are known from sediment cores in the Kara and Laptev Sea, where they co-occur with high inputs of magnetic minerals from the Putorana basalts (e.g., Stein et al., 2004), which doesnot seem to be the case for our boreholes. Alternatively, authigenic ferrimagnetic minerals such as greigite may have formed at the transition from brackish to normal-marine salinities as inferred for early Holocene sediments in the Baltic and Kara Seas (Sohlenius, 1996; Polyak et al., 2002). The lower unit in Borehole 2 has two intervals with high magnetic susceptibility (Fig. 7), which also contain high amounts of pyrite grains (see below)

\subsubsection{Grain size and mineral composition of sediments}

The grain size distribution in sediment cores under study shows a distinct change in the sedimentary environment. The bottom of Borehole 1 (4.69-5.5 m) is composed of a pebbly and gravelly layer overlain by a silt and sand deposit with a peak of gravel (62\%) in its upper part (2.4-3.5 m). The upper unit in Borehole $1(0-2.4 \mathrm{~m})$ is a silty mud with sand content increasing upward. In Borehole 2, the upper unit $(0-7 \mathrm{~m})$ is composed of predominantly silty mud, whereas the lower unit comprises sandy to silty strata with inclusions of rounded gravel at 7.4, 8.5, 9.2, and $10 \mathrm{~m}$. Increased coarse-grained content and variable, mostly poor sorting in the lower unit presumably indicates higher hydrodynamic environments, possibly related to low sea levels, as opposed to overall finer grained and better sorted Holocene sediments of the upper unit.

The composition of heavy minerals is quite diverse, normally from 18 to 30 minerals in a sample including mostly black ore minerals (1.9-51.8\%, mainly pyrite), monocline pyroxenes (2-22.8\%, primarily augite), amphiboles (1-25.9\%, commonly hornblende), epidote and zoisite (2-34.7\%, epidote predominantly), zircon (2-16\%), garnet (1-8.8\%) and titanium minerals (3-21.2\%). The content of other minerals typically does not exceed $5-10 \%$. Down-core variation in the proportion of main rock-forming mineral clasts (epidote-zoisite, feldspar and hornblende) appears to be consistent with the lithostratigraphic division of both boreholes (Figs. 9A and 10A).
Some intervals in the lower unit in Borehole 2 contain high amounts of siderite aggregates $(5.35-6.23 \mathrm{~m})$ or pyrite $(8.38-8.96 \mathrm{~m}$ and $10.4-$ $11.75 \mathrm{~m}$ ); the latter are characterized by high magnetic susceptibility values, probably in relation to ferrimagnetic minerals accompanying the pyritization process. Pyrite is represented by angular grains with uneven surfaces with prominences. These grains resemble remnants of plants replaced with sulfides.

\subsection{Biostratigraphy}

\subsubsection{Spores and pollen}

Spore and pollen spectra studied in two boreholes suggest a twomember structure of the palynostratigraphy of the recovered sediment. The lower member was formed in a relatively warm climate, when taiga woods with fur, Siberian pine, and birch occupied this area. The upper member indicates a forested tundra or tundra proper vegetation type (Figs. 9C and 10C).

Forest spectra found in the bottom part of the lower unit in Borehole 1 (3.7-5.5 m) are typical for a relatively warm climate (Fig. 9C). The spectra consist mainly of tree and shrub species indicating that pine and birch woods with fur, alder, willow, hazel and rare deciduous species occupied the adjacent land. Hydrophilous, swamp species were most abundant among the herbs. Areas free of woods were probably negligible. The climate was overall warmer than today. Up the section (2.9-3.6 m), palynomorphs indicate colder environments. The vegetation type corresponds to a forested tundra, where shrubs and herbs predominate. In the upper unit (1.6-2.3 $\mathrm{m})$, the vegetation becomes completely tundra-type, indicating deteriorated climatic conditions. Herbs predominate (73-83\%), while shrubs are represented by willow Salix sp. (10-17\%), Betula sect. nanae (5-6\%), and Alnaster sp. (2-3\%). The subsurface interval $(0-0.6 \mathrm{~m})$ is predominated by herbs and shrubs typical for the contemporary tundra.

Succession of palynomorph spectra in Borehole 2 is generally similar to Borehole 1 (Fig. 10C). The lower unit (7-11.75 m) has high numbers of spores and pollen as well as plant and coal fragments. Pine pollen predominate the spectra, which also have a considerable birch component, with fur, alder, willow, hazel, and rare deciduous species. Among the herbs, coastal and aqueous species dominated. These spectra indicate a relatively warm climate with widespread forests on the adjacent land.

The lower part of the upper unit has palynomorph spectra somewhat similar to the underlying sediments, which may be related to redeposition from older strata at the initial stages of the transgression, as discussed below. Up-section (between 3.16 and $5.1 \mathrm{~m}$ ), spores and pollen clearly suggest a cooling of the climate. Tundra species (B. sect. nana) and herbs grew in abundance. Forested areas must have decreased or possibly turned into "islands" in the tundra, where pine was suppressed, but some minor deciduous species were still present. The spectrum of the sample taken from the 3-m depth resembles those from below, but thermophilic species, both trees and herbs, are totally 


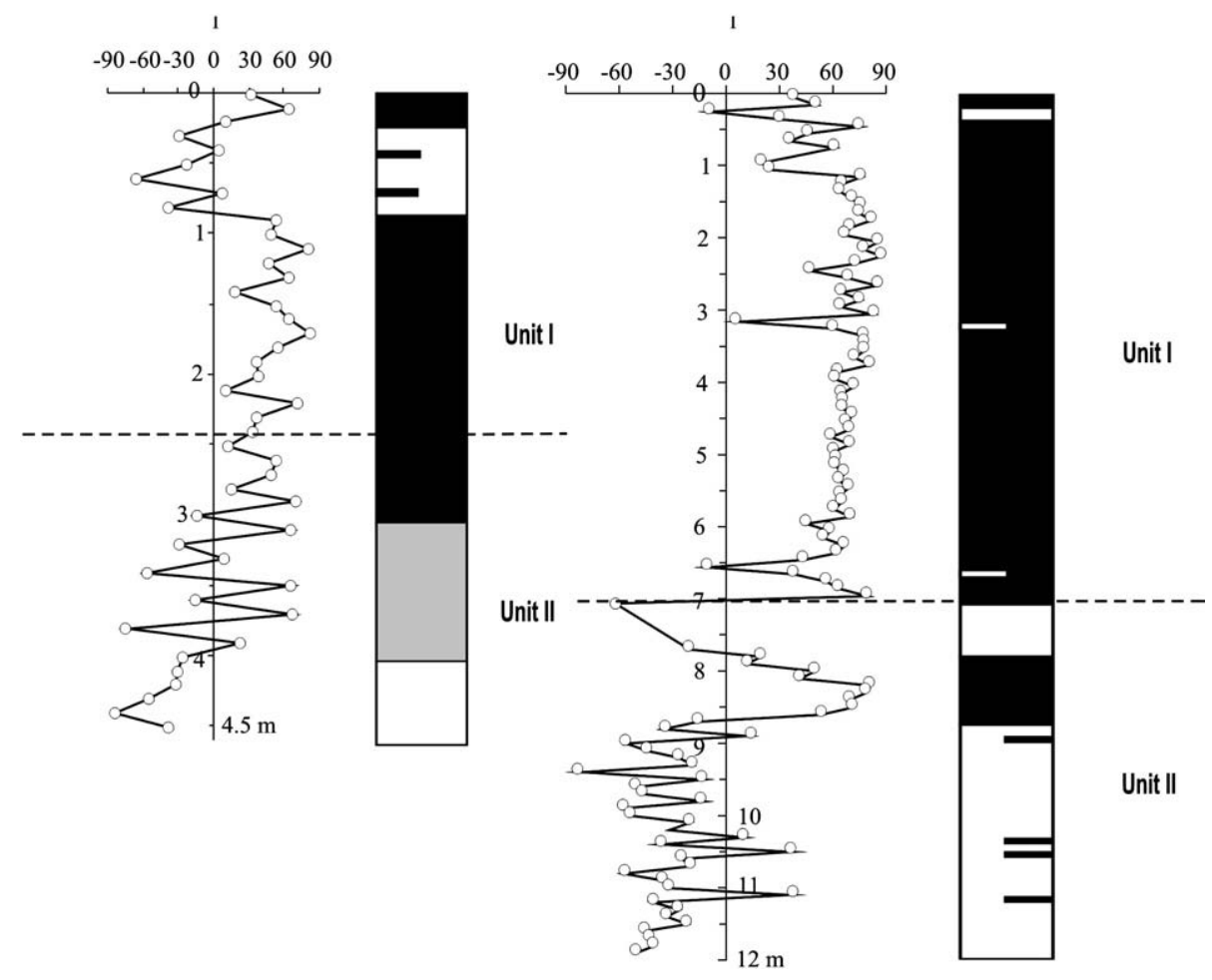

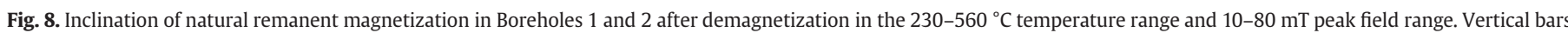
show predominant magnetization: white - normal, black - reverse, grey - transitional.

absent in this sample. Spores and pollen occur in notably lower numbers, and microfossils are often broken and poorly preserved. The palynomorph assemblage in the uppermost interval $(0-0.74 \mathrm{~m})$ primarily consists of spore herbs (56-70\%), which documents further cooling and transition to the tundra vegetation type, close to modern.

The forested Arctic coasts with pine and birch woods, as indicated by spore and pollen spectra in the lower unit of both boreholes, likely existed in the Pliocene and some intervals in the Early Pleistocene as exemplified by the Pestsovskaya Suite on the Chukotka Peninsula (Petrov, 1966) and the Gubik Formation on the north coast of Alaska (Brigham-Grette and Carter, 1992). The upper units are characterized by tundra and forested tundra vegetation typical of the later portions of the Pleistocene.

\subsection{Benthic foraminifers}

In the lower unit in both boreholes except for one sample in Borehole 2 no foraminifers were found, which possibly indicates nonmarine or coastal environments (Figs. 9 and 10). The interval of $0.8-$ $3.0 \mathrm{~m}$ in Borehole 1 contains several species of calcareous benthic foraminifers, such as Haynesina orbicularis, characteristic of coldwater, Arctic to Boreal environments, commonly with reduced salinity. In the upper part of the core $(0-0.6 \mathrm{~m})$ the foraminiferal assemblages comprise between 25 and 34 species including Bucella spp., Elphidium spp., polymorphinids and more, as well as some agglutinated foraminifers

In the lower unit of Borehole 2, only one sample (8.32-8.38 m) contains foraminifers represented by five species, mostly elphidiids. Up the core, until $5.1 \mathrm{~m}$ depth (upper unit), no foraminifers occur. Samples from the interval 3.54-5.1 m contain from 6 to 11 species, predominated by elphidiids. Agglutinated forms and tiny juvenile underdeveloped shells are abundant. Also found in these samples are Elphidium oregonense, Retroelphidium selseyense, Sigmomorphina sp., and Quinqueloculina longa, which are common for Pliocene to Lower Pleistocene deposits as reported for the north of the Chukotka Peninsula (Petrov, 1966). In the interval 1.05-3.2 m samples contain from 15 to 34 species, and overall abundance increases. Between 1.05 and $3.20 \mathrm{~m}$ foraminifers are scarce and include Arctic or Arctic-Boreal species typical for shallow-water and cold marine environments. The uppermost part of the borehole $(0-1.05 \mathrm{~m})$ is characterized by rich foraminiferal assemblages containing between 15 and 23 species.

In addition to foraminifers, ostracodes also occur in the upper unit. In the top $0.6 \mathrm{~m}$ of Borehole 1 and above $3.7 \mathrm{~m}$ in Borehole 2 ostracode assemblages are common for Arctic marine environments. In contrast, abundant ostracodes in the interval between 5.35 and $5.42 \mathrm{~m}$ in Borehole 2 include only fresh-water species such as Cytherissa lacustris, Candona spp., and Ilyocypris bradyi. These ostracodes co-occur with foraminifers indicative of Pliocene to Lower Pleistocene deposits as reported above.

\subsection{Diatoms}

Diatoms occur mainly in the upper unit, where their numbers vary from 120 valves/g to $6.1 \mathrm{mln}$ valves/g. Diatom assemblages in these sediments are represented mainly by sublittoral species (Paralia sulcata), cold-water neritic (Thalassiosira antarctica $+T$. gravida, T. nordenskioldii, spores of Chaetoceros), and ice-related neritic species (Fossula arctica, Fragilariopsis oceanica, etc.) that indicate severe ice conditions and a generally minor influence of Bering Sea waters (Polyakova, 1997).

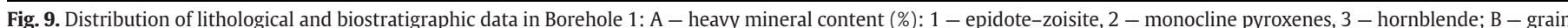

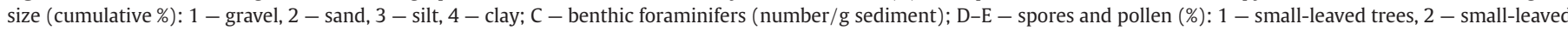

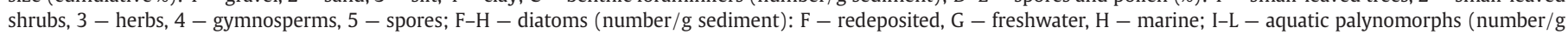
sediment): I - acritarchs, J - organic linings of foraminifers, $\mathrm{K}$ - green algae, $\mathrm{L}$ - dinocysts. ${ }^{14} \mathrm{C}$ ages are shown next to curve $\mathrm{C}$. Vertical shadings show subunits in Unit I. 


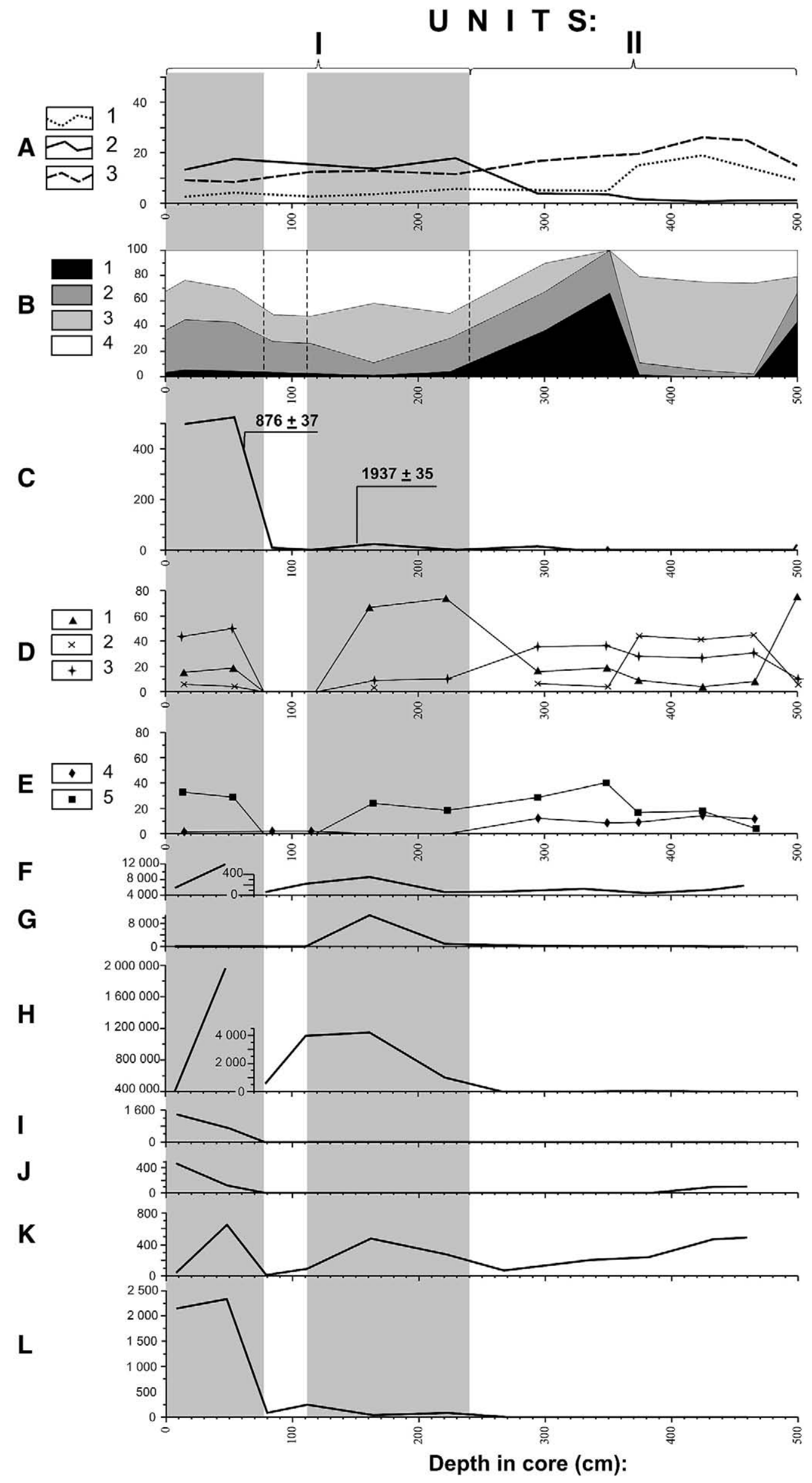




\section{U N I T S:}

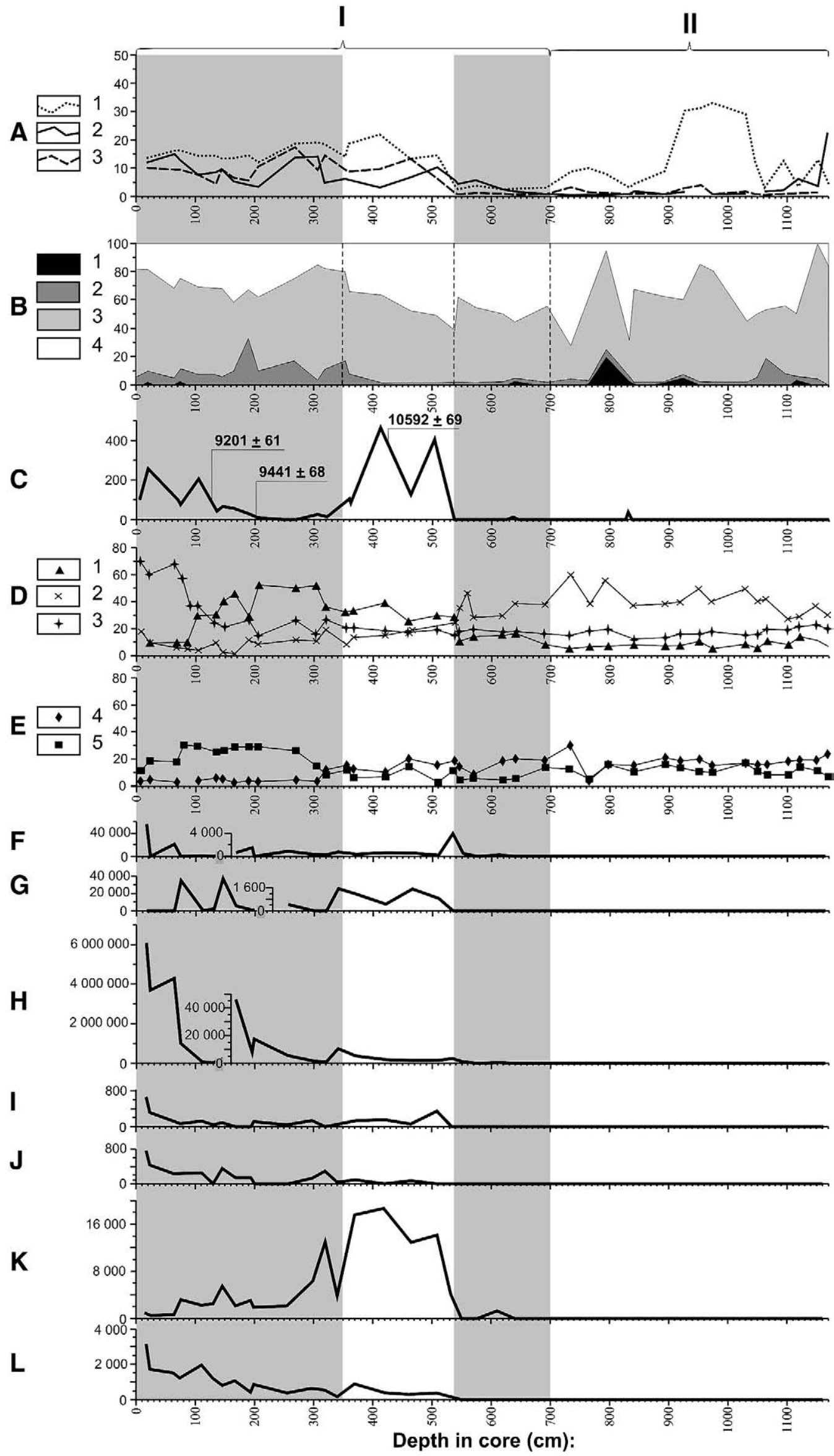


In the lower unit diatoms have been found only in Borehole 1 (2.4$5.0 \mathrm{~m}$ ), where they occur as sporadic fragments of the valves of marine diatoms Pyxidicula and Hemiaulus as well as freshwater diatoms (Aulacoseira subarctica, Diatoma hyemalis, Frustulia vulgaris, and some others) in the interval 2.65-3.8 m (Fig. 9G).

In Borehole 2 diatoms appear in the lower part of the upper unit (5.4-6.13 m) as rare and likely redeposited valve fragments of Coscinodiscus, Paralia, Thalassiosira, and Pyxidicula (Fig. 10F). The interval 3.4-5.4 m features a steady increase in the number of diatoms (from 3.3 to 12,000 valves/g) mostly composed of marine and brackish-marine species, which are common for the modern diatom flora of Arctic seas. Between 2.69 and $3.40 \mathrm{~m}$ diatoms are rare, with ice-related species ( $F$. arctica and $F$. oceanica) reaching $22 \%$ in the upper part of this interval. Highest numbers reaching several million valves / $\mathrm{g}$ occur in the upper part of the core $(0.17-2.69 \mathrm{~m})$, as well as in the upper-most part of Borehole 1 (Figs. $9 \mathrm{H}$ and $10 \mathrm{H}$ ). Marine diatoms predominate (58-100\%) and include largely the sublittoral species (e.g., P. sulcata, T. hyperborea v. septentrionalis) and cold-water neritic and panthalassic species ( $T$. antarctica $+T$. gravida, Coscinodiscus oculusiridis, Rhizosolenia hebetata f. hebetata, and Chaetoceros spores). Nevertheless, the content of freshwater diatoms (Pinnularia borealis, $P$. brevicostata, P. major, Eunotia praerupta, and more) exceeds $10 \%$ in some intervals throughout the upper unit reflecting a considerable contribution of river discharge (Fig. 10G).

The rough-testaceous valves of Pyxidicula zabelinae as well as some other species (Cosmiodiscus insignis, T. punctata, T. manifesta, T.yabei, P. schenckii) found in the lower unit in Borehole 1 and lower part of the upper unit in Borehole 2 are typical for Neogene deposits of the North Pacific (Koizumi, 1992; Barron and Gladenkov, 1995; Yanagisawa and Akiba, 1998). Some scarce but stratigraphically important species occurring in these samples, such as the valves of T. nidulus $+T$. jouseae, have the Last Appearance Datum in the North Pacific at $0.28 \mathrm{Ma}$. The presence of morphologically diverse and commonly abundant representatives of species of Actinocyclus is indicative of the Late Pliocene to Early Pleistocene (Zhuze, 1962, 1969; Stepanova, 1990; Loseva, 1992; Polyakova, 1997).

\subsection{Aquatic palynomorphs}

Similar to diatoms, aquatic palynomorphs (dinocysts, green algae, acritarchs, and organic linings of foraminifers) are found mostly in the upper unit, with concentrations varying from 0 to 20,000 specimens/g. The lower unit in Borehole 1 contains only scarce freshwater green algae such as Botryococcus cf. braunii and Pediastrum boryanum. Similar algae occur in much larger numbers in the lower part of upper unit in this core $(0.78-2.2 \mathrm{~m})$, and especially between 2.69 and $5.39 \mathrm{~m}$ in Borehole 2 (Fig. 9K and 10K).

In the upper part of the upper unit dinocysts are most abundant in both cores (Figs. 9L and 10L). Their assemblages in Borehole 1 are dominated by cold-water heterotrophic species Islandinium minutum, Islandinium? cezare, Echinidinium karaense, and Brigantedinium spp. The latter species might indicate somewhat elevated productivity, and thus the advection of the Bering Sea water (Radi and de Vernal, 2004). Borehole 2 contains more of relatively warm-water, authotrophic species such as Pentapharsodinium dalei and Spiniferites elongates, indicative of the Bering Sea water inflow. The upper-most sediment in this core has a high content of an authotrophic species Operculodinium centrocarpum (up to $32 \%$ ). Altogether, dinocyst assemblages in this core are common for modern and Holocene environments in the central Chukchi Sea (Radi et al., 2001).

\subsection{Organic matter}

Organic matter was studied in Borehole 2. The pattern of distribution of organic carbon (Corg) and total carbonate (Ccarb) is generally consistent with changes in litho- and biostratigraphy (Fig. 11). In the uppermost interval $(0-3.16 \mathrm{~m})$ the contents of Corg and Ccarb $(0.72 \%$ and $0.05 \%$, respectively) correspond to the background levels of modern and Holocene deposits of the Arctic shelves (Organic Matter of Bottom Sediments from World Ocean Polar Regions, 1990). Down-core in the upper unit, Corg content decreases from $0.95 \%$ to $0.51 \%$, which may be related to early diagenesis. An apparent co-variation between the Corg and Ccarb points to their genetic interrelation, i.e., participation of aqueous organisms in the production of organic matter in the Holocene deposits (Romankevich and Vetrov, 2001). In the lower part of the upper unit (below $4 \mathrm{~m}$ ) the interrelation between the Corg and Ccarb disappears and the distribution of Corg becomes patchier. In particular, in the 4.5-5.4 m interval Corg abruptly increases to $1.82 \%$ while the carbonate level remains low. This can be explained by abrupt changes in the supply of terrigenous humic material, which is corroborated by a similar peak in humic acids (Fig. 11) (Manskaya and Kodina, 1975). Another sharp increase in Corg at 6.13-6.23 m may be related to a secondary mineral formation in a shallow-water environment with unstable salinity. The lower unit below $8 \mathrm{~m}$ has distinctly high, up to 3\% contents of Corg and humic acids. This suggests sedimentation in a shallow-water, near-coastal basin in relatively warm climatic conditions, and hence high organic matter supply from the coast.

The molecular composition of hydrocarbons can provide additional information on the environments in which the organic matter was formed. For example, the content of humic material can be indicated by the ratio of alkane hydrocarbons $\mathrm{C17} / \mathrm{C} 29$, which marks aqueous and humic components, correspondingly (Fig. 11) (Kaplan, 1982; Venkatesan et al., 1987; Brassell et al., 1987; Venkatesan and Venkatesan, 1988; Saliot et al., 1991; Yunker et al., 1993). It is also well known that the distribution of the short-chain (C17-19) and longchain (C27-31) alkane hydrocarbons allows us to assess the contribution of aqueous and terrigenous biota in the production of organic matter in bottom sediments (Eglinton and Murphy, 1969; Elias et al., 1997b; Bastow et al., 2001; Peters et al., 2005; Hautevelle et al., 2006; Greenwood et al., 2006). In addition, n-C29 in terrigenous alkanes is considered mainly as an indicator of ground vegetation, while n-C31 is a typical component of peat. In the studied deposits, the content of n-C29 notably increases in the lower unit (Fig. 11), in good agreement with biostratigraphic data suggesting a continental or near-shore sedimentary environment.

The above interpretation is further supported by the distribution of cyclanes. Biogenic cyclanes are formed at the stage of sediment deposition and early diagenesis,. During deeper (post-diagenetic) transformation of the organic matter, cyclanes are modified into geocyclanes, which are thermodynamically more stable (Peters et al., 2005). Geocyclanes in the studied sediments are present only in the Holocene deposits suggesting the input of an already transformed organic matter and the importance of redeposition processes. The lower unit is predominated by biogenic cyclanes, which indicate the proximity of sources of fresh, probably terrigenous organic matter and high burial rates. In particular, the terpenoids in the lower unit are dominated by such components as olean-18-ene and D-friedoolean14-ene (Fig. 11), which are specific taxons of higher terrestrial plants and occur at the earliest stages of organic transformation.

In addition, cadalene and retene were found among aromatic biomarkers (Fig. 11). Cadalene is a marker of higher terrestrial plants, mainly the angiosperms, and retene is a product of transformation of 
U N I T S:
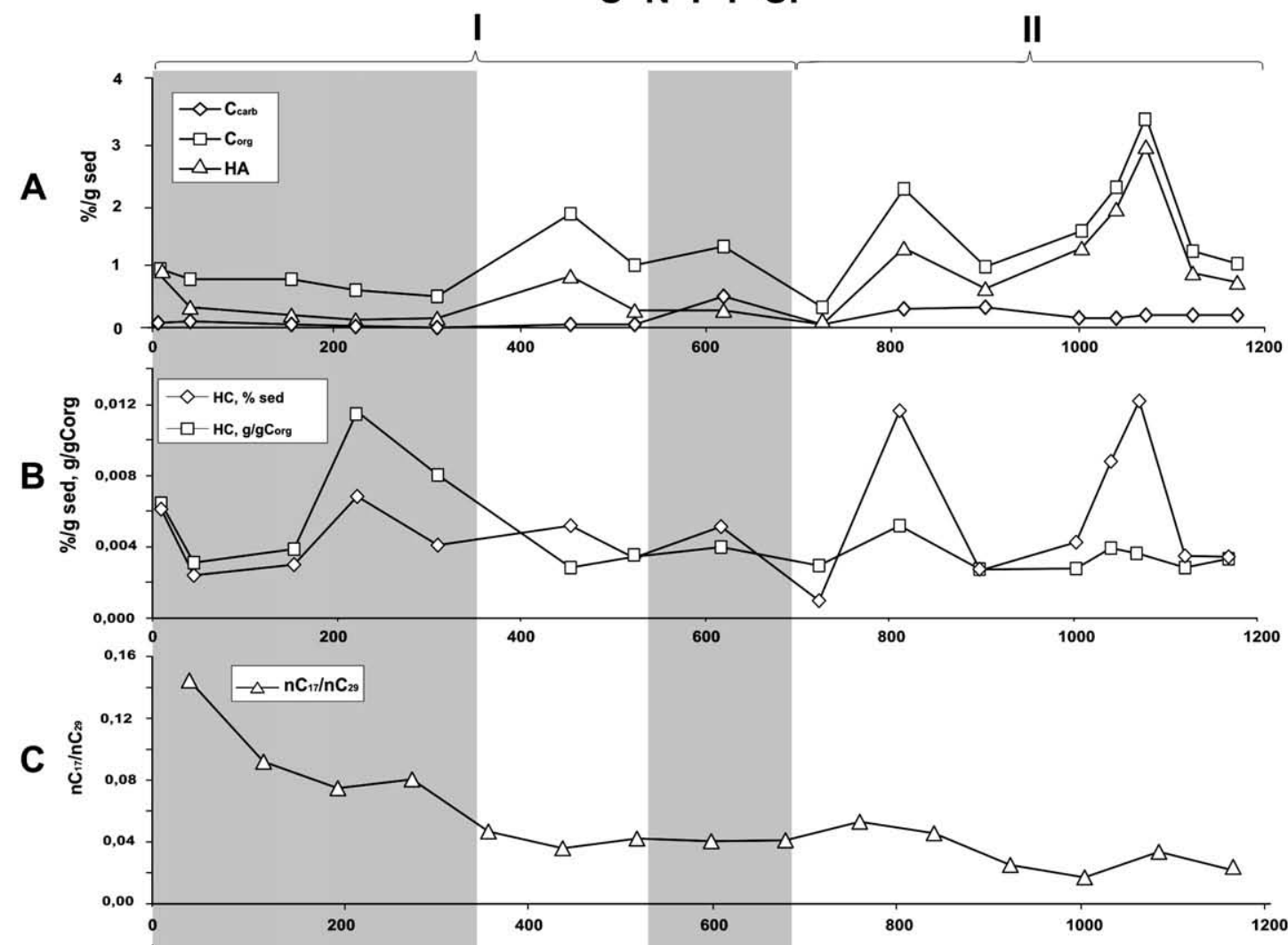

D
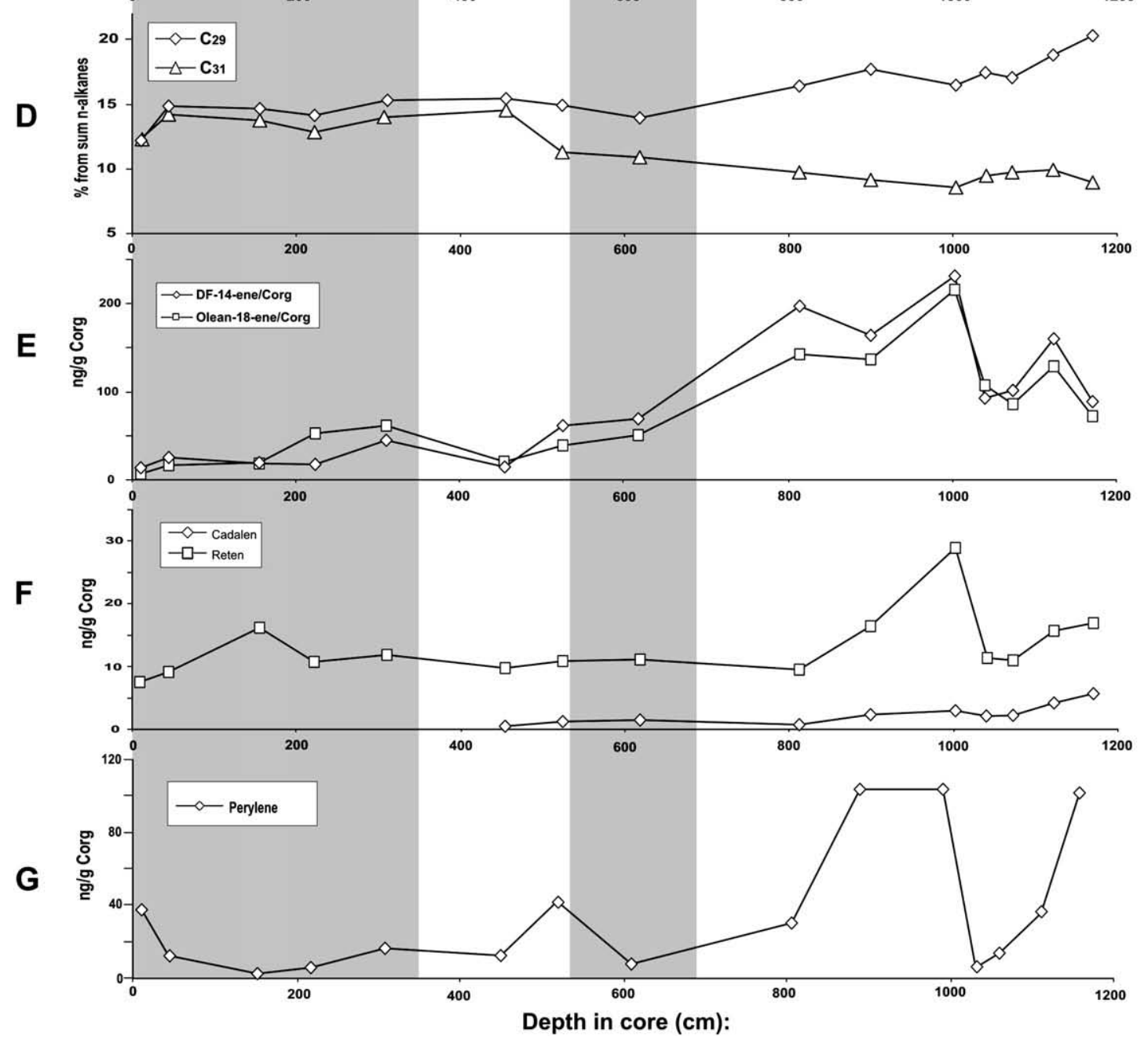
abietans from the resin of coniferous trees. Cadalene in the studied deposits is present only in the lower unit, supposedly related to the warm climate. The content of reten reaches its maximum in the interval with the highest amount of gymnosperm pollen between 9 and $10 \mathrm{~m}$. It is noteworthy that perylene, a polyaromatic biomarker of shallow-water organics formed under reducive conditions, increases in the same interval.

\section{Discussion}

\subsection{Stratigraphy}

The stratigraphic division of both boreholes into two units is supported by the entire complex of lithologic, biostratigraphic, paleomagnetic, and seismo-acoustic data. Radiocarbon dating of mollusk shells recovered from the upper unit shows the early and late Holocene ages for Boreholes 2 and 1, respectively (Table 2; Figs. 6 and 7). These ages indicate that marine deposition in the study area resumed during the last, postglacial sea-level rise. Different ages at the two sites likely result from different water depths as well as erosional processes, which are especially strong in the nearshore zone represented by Borehole 1 .

Sediments of the lower unit, separated by an erosional unconformity in both boreholes, are characterized by predominantly negative magnetization values. These sediments may belong to the last paleomagnetic reversed-polarity epoch (Matuyama, 0.73-2.48 Ma), and the interval of normal magnetization at 7.7-8.6 $\mathrm{m}$ in Borehole 2 could then correspond to the Jaramillo event. However, as the depth of erosion is unknown, the lower unit may represent an even older paleomagnetic epoch with the reverse geomagnetic polarity.

Spore and pollen spectra from the upper unit in both boreholes portray tundra to forested-tundra environments, with a progressive deterioration of climate from the early to late Holocene. In contrast, palynomorphs from the lower unit, except for its upper part in Borehole 1, indicate a much warmer climate, when taiga woods with fir, Siberian pine, and birch were widespread on the territory adjacent to the southern Chukchi Sea. Such palynological spectra can be compared with those of the Pliocene to Lower-Pleistocene Pestsovskaya Suite of the Chukotka Peninsula (Petrov, 1966) and warm intervals of the Gubik Formation of Alaska with estimated ages between 2 and $3 \mathrm{Ma}$ (Brigham-Grette and Carter, 1992).

The combination of the reverse polarity of the lower unit with its palynological composition indicative of Pliocene to early Pleistocene environments suggests that this unit was deposited during either the early stages of the Matuyama paleomagnetic epoch $(0.73-2.48 \mathrm{Ma})$ or the previous reverse-polarity epoch (Gilbert, 3.4-5.1 Ma). The lower unit in Borehole 1 contains a transition from reverse to normal polarity between ca. 3 and $4 \mathrm{~m}$ corresponding to a change in palynospectra from relatively warm and forested to colder, forested-tundra environments. This transition may mark the boundary between the Gilbert and Gauss paleomagnetic epochs ca. 3.4 Ma or one of the normalpolarity events within Matuyama.

Some benthic foraminiferal species such as $E$. oregonense, $R$. selseyense, and Sigmomorphina sp., occurring in the lower part of the upper unit in Borehole 2 (notably between 3.5 and $5.1 \mathrm{~m}$ ), are common for Pliocene to Lower Pleistocene deposits of the Chukotka Peninsula (Petrov, 1966). These species co-occur in our samples with freshwater ostracodes and green algae as well as diatoms indicative of Pliocene to early/middle Pleistocene such as $T$. nidulus $+T$. jouseae and Actinocyclus spp. These exotic microfossils probably result from reworking from older strata at the beginning of the last transgression. The source sediment likely outcropped nearby, as indicated by the abundance and good condition of redeposited tests. The high contents of organic carbon and humic acids at this interval also indicates local redeposition from deposits of the lower unit enriched with terrestrial organic matter.

\subsection{Depositional history}

Multiple outcrops of Pliocene and Pleistocene deposits of the Chukotka Peninsula (Petrov, 1966; Brigham-Grette et al., 2001), Alaska (Brigham-Grette and Carter, 1992; Brigham-Grette and Hopkins, 1995; Khim et al., 2001), and Wrangel Island (Avdyunichev, 1990; Gualtieri et al., 2003), along with marine geological data (Grantz et al., 1978; Phillips et al., 1988a; McNeil et al., 2001; Keigwin et al., 2006; Hill et al., 2007), evidence that the shelf and coasts of the Chukchi Sea were repeatedly subjected to sea-level transgressions and regressions. Existing seismic-reflection and sediment core data suggest that the shallow Chukchi shelf was the area of net erosion during that time period, as indicated by several generations of valleys and channels incised into older, Cretaceous or possibly Early Cenozoic strata and covered only by a thin veneer of sediments of the last transgression (Grantz et al., 1978; Phillips et al., 1988a; Hill et al., 2007). Our data suggest that the western part of the Chukchi Sea contains thicker Pliocene/Pleistocene deposits infilling broad valleys incised into sedimentary bedrock (Fig. 4). This conclusion is consistent with prior results of drilling in the nearshore areas in the western part of the sea (Puminov, 1981).

The valley infill is characterized by a distinct acoustic signature with mostly inclined, unevenly spaced bedding and is separated by unconformities from both the bedrock and the uppermost subhorizontal beds (Figs. 4 and 7). Our boreholes recovered the upper strata of this seismic unit (lower lithostratigraphic unit), thus enabling the assessment of its age and depositional environments.

As discussed above, the most likely age of the lower lithostratigraphic unit is Pliocene to early Pleistocene (broadly between ca. 5 and $2 \mathrm{Ma}$ ), based on reverse paleomagnetic polarity of these sediments and the palynological composition indicative of relatively warm climate and forested coasts. The coarse, poorly sorted grain-size composition of the lower unit in Borehole 1, combined with an absence of marine microfossils (except for a few diatom fragments) and abundance of green algae, suggests that it was deposited in continental, possibly alluvial environments. In Borehole 2 recovered further away from the coast, the lower unit comprises beds of sandy and silty sediments, which contain meager foraminifers at least at one interval. We infer that these sediments were deposited in a shallowmarine, probably near-coastal area. The intermittent occurrence of siderite or pyrite indicates the likelihood of alternating freshwater and shallow marine facies. The composition of organic carbon demonstrates high input of fresh, terrigenous organic material, which is also indicative of either continental or near-coastal environments.

The inferred Pliocene to early Pleistocene age of the lower lithostratigraphic unit, combined with its correlation to a widespread seismic unit that infills a broad valley incised into bedrock over much of the southwestern Chukchi shelf (South Chukchi Plain; Figs. 3 and 4), suggests the possibility that this deposit was related to the initial opening of the Bering Strait and its subsequent submergence. However, the existing age control is insufficient for relating the recovered sediments to a specific transgression following the Bering Strait opening.

The upper unit in both boreholes is clearly related to the last, postglacial transgression, although the initiation of marine deposition differs in time between the two sites. In Borehole 2 the oldest ${ }^{14} \mathrm{C}$ age of ca. 11 cal. ka is generally consistent with the bathymetric position relative to sea-level rise on the unglaciated Eastern Siberian shelf

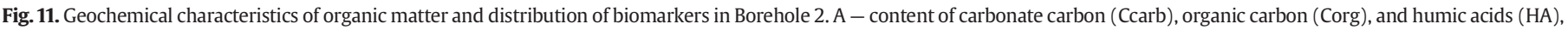

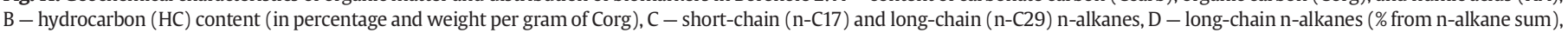
E-D-Friedoolean-14-ene and Olean-18-ene (ng/g Corg), F - retene and cadalene (ng/g Corg), G - perylene (ng/g Corg). Vertical shadings show subunits in Unit I. 
(Bauch et al., 2001). The early Holocene sediments in Borehole 2 had fairly high sedimentation rates of several meters per thousand years, which is common for the early stages of Arctic shelf flooding (e.g., Stein et al., 2004). Such flooding involves fast sediment filling of local seafloor depressions and extensive reworking of deposits from adjacent higher-elevated areas. Sonar profiler record from the borehole site shows inclined reflectors for this interval grading upwards into subhorizontal bedding (Fig. 7), which indicates the replacement of channel-type deposition by normal marine environments. Successive deposition in Borehole 2 was very low, with only one meter of sediment deposited in ca. $9 \mathrm{kyr}$. This was possibly related to sea-level stabilization, but also to a climatic deterioration and, thus, more severe sea-ice conditions after the relatively warm early Holocene (CAPE, 2001). The latter suggestion is corroborated by a simultaneous change in palynospectra in Borehole 2 from forested-tundra to tundra proper assemblages.

In contrast to Borehole 2, deposition in Borehole 1 resumed as late as ca. 2 cal. ka, assuming generally even sedimentation rates in the lithologically homogenous lower part of the upper unit. This estimated age is much later than the end of sea-level rise. The delay could result from predominantly erosional processes and the patchiness of depositional areas in the coastal zone. Another possibility is that the site of Borehole 2 has been part of an isthmus that presumably connected the Wrangel Island with the Chukotka Peninsula until as late as ca. 2 ka based on the distribution of mammoth remnants (Vartanyan et al., 1995). It seems likely that the late Holocene deposition in Borehole 1 is related to the formation of nearshore bars, which are common for the Eastern Siberian shelves and have been identified by sidescan records just a few kilometers west of the borehole site (Fig. 5).

\section{Conclusions}

Two shallow boreholes drilled in the southwestern Chukchi Sea between the mainland and the Wrangel Island recovered sediments of two principal stratigraphic units. The upper unit correlates to the uppermost, well stratified seismic unit that is related to the last, postglacial transgression across the Chukchi Sea (McManus et al., 1983; Keigwin et al., 2006; Hill et al., 2007) and contains Holocene ${ }^{14} \mathrm{C}$ ages in an orderly succession. In Borehole 2 farther offshore, transgressive sedimentation started at ca. $11 \mathrm{ka}$ and was characterized by fast deposition due to the infillment of local seafloor depressions (channels), with extensive redeposition of sediment from older strata. Further up-core sediment was slowly deposited in quiet, probably ice covered marine environment similar to the modern conditions. This depositional succession was accompanied by climatic change as indicated by a shift in attendant spore and pollen assemblages from forested tundra to tundra proper. Deposition in Borehole 1 resumed in the late Holocene, possibly in relation to a change in the pattern of coastal erosional processes and/or the demise of a landbridge between the Chukotka Peninsula and the Wrangel Island, as indicated by data from mammoth remnants (Vartanyan et al., 1995).

Based on paleomagnetic and palynological data, the age of the lower lithostratigraphic unit in both boreholes can be broadly estimated as Pliocene to Early Pleistocene (ca. 5-2 Ma). Palynospectra in these deposits indicate conditions considerably warmer than present, with pine, birch, and spruce forests occupying the coasts of the Chukotka Peninsula currently covered by tundra. Similar vegetation grew at the northern Alaskan coast during the warm periods of the Pliocene to Early Pleistocene until it was completely replaced by tundra some time between ca. 2 and 2.5 Ma (Brigham-Grette and Carter, 1992). This lithostratigraphic unit can be correlated to the seismic unit broadly distributed in the western Chukchi Sea, where it fills valleys incised into the sedimentary bedrock of presumably Cretaceous to early Cenozoic age. Our stratigraphic results suggest that this unit was deposited during a transgression following the opening of the Bering Strait, although the exact age of these deposits and their relationship to the Bering Strait history requires more drilling on the Chukchi continental margin.

\section{Acknowledgments}

This research was performed within the framework of the Russian Federation program of geological mapping of the continental shelf. Radiocarbon ages were partly supported by the US National Science Foundation award ARC-0612473 to L. Polyak. Authors express their gratitude to all participants and crew members of the expedition of 2006, as well as drilling engineers and designers A.A. Karakozov, P.L. Komar, and A.V. Khokhulya (Donetsk National Technical University, Ukraine), Yu.P. Egorov and V.V. Bol'shikov (VNIIOkeangeologia). L.S. Smirnova (VNIIOkeangeologia) helped with grain-size and mineralogic analyses; C.A. Pshenichny assisted with the English translation; L. Polyak and two anonymous reviewers provided numerous helpful suggestions to the paper.

\section{References}

Avdyunichev, V.V. 1990. Morphostructures and Cenozoic paleoenvironments of the Wrangel Island. Geology, lithodynamics and alluvial deposit forming in Arctic littoral zones. L, 76-84 (in Russian).

Barron, J.A., Gladenkov, A.Y., 1995. Early Miocene to Pleistocene diatom stratigraphy of Leg 145. In: Rea, D.K., Basov, I.A., Scholl, D.W., Allan, J.F. (Eds.), Proc. ODP, Sci. Results, vol. 145. TX (Ocean Drilling Program), College Station, pp. 3-19.

Bastow, T.P., Singh, R.K., van Aarssen, B.G.K., Alexander, R., Kagi, R.I., 2001. 2-Methylretene in sedimentary material: a new higher plant biomarker. Org. Geochem. 32 (10) 1211-1217.

Bauch, H.A., Mueller-Lupp, T., Taldenkova, E., Spielhagen, R.F., Kassens, H., Grootes, P.M., Thiede, J., Heinemeier, J., Petryashov, V.V., 2001. Chronology of the Holocene transgression at the North Siberian margin. Global Planet. Change 31, 125-139.

Brassell, S., Eglinton, G., Howell, V., 1987. Paleoenvironmental assessment of marine organic-rich sediments using molecular organic geochemistry. In: Brooks, J, Fleet, A (Eds.), Marine Petroleum Source Rocks, Geol. Soc. Spec. Publ., vol. 26, pp. 79-98.

Brigham-Grette, J., Carter, L.D., 1992. Pliocene marine transgressions of northern Alaska: circumarctic correlations and paleoclimatic interpretations. Arctic 45, 74-89.

Brigham-Grette, J., Hopkins, D.M., 1995. Emergent marine record of the last interglaciation and paleoclimate along the northwest Alaskan coast. Quat. Res. 43, 159-173.

Brigham-Grette, J., Hopkins, D.M., Ivanov, V.F., Basilyan, A.E., Benson, S.L., Heiser, P.A. Pushkar, V.S., 2001. Last Interglacial (isotope stage 5) glacial and sea level history of coastal Chukotka Peninsula and St. Lawrence Island, Western Beringia. Quat. Sci. Rev. 20, 419-423.

CAPE Project Members, 2001. Holocene paleoclimate data from the Arctic: testing models of global climate change. Quat. Sci. Rev. 20, 1275-1287.

Creager, J.S., McManus, D.A., 1965. Pleistocene drainage patterns on the floor of the Chukchi Sea. Mar. Geol. 3, 279-290.

Eglinton, G., Murphy, M.T.J., 1969. Organic Geochemistry: Method and Results. Springer, Berlin. 828 pp.

Elias, S.A., Short, S.K., Nelson, C.H., Birks, H.H., 1997a. Life and times of the Bering land bridge. Nature 382, 60-63. doi:10.1038/382060a0.

Elias, V.O., de Barros, A.M.A., de Barros, A.B., Simoneit, B.R.T., Cardoso, J.N., 1997b. Sesquiterpenoids in sediments of a hypersaline lagoon: a possible algal origin. Org. Geochem. 11, 721-730.

Gladenkov, A.Yu., Gladenkov, Yu.B., 2004. Onset of connections between the Pacific and Arctic Oceans through the Bering Strait in the Neogene stratigraphy. Geol. Correl. 12 (2), 72-89 (in Russian).

Grantz, A., Holmes, M.L., Kososki, B.A., 1975. Geologic framework of the Alaskan continental terrace in the Chukchi and Beaufort Seas. Canada's Continental Margins and Offshore Petroleum Exploration. Canadian Society of Petroleum Geologists Memoir, vol. 4, pp. 669-700.

Grantz, A., Mann, D.M., May, S.D., 1978. Multichannel seismic-reflection data collected in 1978 in the Eastern Chukchi Sea. US Geological Survey Open File Report, pp. 86-206

Greenwood, P.F., Leenheer, J.A., McIntyre, C., Berwick, L., Franzmann, P.D., 2006. Bacteria biomarkers thermally released from dissolved organic matter. Org. Geochem. 37, 597-609.

Gualtieri, L., Vartanyan, S., Brigham-Grette, J., Anderson, P.M., 2003. Pleistocene raised marine deposits on Wrangel Island, northeast Siberia and implications for the presence of an East Siberian ice sheet. Quat. Res. 59 (3), 399-410. doi:10.1016/ S0033-5894(03)00057-7.

Hautevelle, Y., Michels, R., Malartre, F., Trouiller, A., 2006. Vascular plant biomarkers as proxies for paleoflora and paleoclimatic changes at the Dogger/Malm transition of the Paris Basin (France). Org. Geochem. 37 (5), 610-625. doi:10.1016/j. orggeochem.2005.12.010.

Hill, J.C., Driscoll, N.W., Brigham-Grette, J., Donnelly, J.P., Gayes, P.T., Keigwin, L., 2007 New evidence for high discharge to the Chukchi shelf since the Last Glacial Maximum. Quat. Res. 68 (2), 271-279.

Hramov, A.N. (Ed.), 1982. Paleomagnetology. Nedra, L.. 312 pp. (in Russian). 
Jakobsson, M., Macnab, R., Mayer, L., Anderson, R., Edwards, M., Hatzky, J., Schenke, H.W., Johnson, P., 2008. An improved bathymetric portrayal of the Arctic Ocean: implications for ocean modeling and geological, geophysical and oceanographic analyses. Geophys. Res. Lett. L07602. doi:10.1029/2008gl033520.

Kalinichenko, O.I., Karakozov, A.A., Zybynskiy, P.V., 2001. New methods and technology of marine drill system for drilling on shelf. Scientific Proceedings, Donetsk State University. Geological series, vol. 36, pp. 144-148 (in Russian).

Keigwin, L.D., Donnelly, J.P., Cook, M.S., Driscoll, N.W., Brigham-Grette, J., 2006. Rapid sea-level rise and Holocene climate in the Chukchi Sea. Geology 34 (10), 861-864. doi: $10.1130 /$ G22712.1

Khim, B.-K., Krantz, D.E., Brigham-Grette, J., 2001. Stable isotope profiles of Last Interglacial (Pelukian Transgression) mollusks and paleoclimate implications in the Bering Strait Region. Quat. Sci. Rev. 20 (1-3), 463-483. doi:10.1016/S0277-3791(00)00104-9.

Kirschvink, J.L., 1980. The least squares lines and plane analysis of paleomagnetic data. Geophys. J. R. Astron. Soc. 62, 699-718.

Kochegura, V.V. 1992. Application of Paleomagnetic Methods for the Geological Survey of the Shelf with scale 1:50 000. VSEGEI, St. Petersburg, 144 pp. (in Russian).

Koizumi, I., 1992. Diatom biostratigraphy of the Japan Sea: Leg 127. In: Pisciotto, K.A., IngleJr. Jr., J.C., von Breymann, M.T., Barron, J., et al. (Eds.), Proc. ODP, Sci. Results, vol. 127/128 (Pt. 1). TX (Ocean Drilling Program), College Station, pp. 249-289.

Loseva, E.I., 1992. Atlas of Pleistocene Marine Diatoms from European North-West Part of USSR. Nauka, SPb. 272 pp. (in Russian).

Manskaya, S.M., Kodina, L.A., 1975. Lignine Geochemistry. Nauka, Moscow. 230 pp. (in Russian).

Marincovich Jr., L., Gladenkov, A.Y., 2001. New evidence for the age of Bering Strait. Quat. Sci. Rev. 20 (1-3), 329-335. doi:10.1016/S0277-3791(00)00113-X.

McManus, D.A., Creager, J.S., Echols, R.J., Holmes, M.L., 1983. The Holocene transgression on the Arctic flank of Beringia: Chukchi valley to Chukchi estuary to Chukchi Sea. In: Masters, P.M., Flemming, N.C. (Eds.), Quaternary Coastlines and Marine Archaeology. Academic Press, London, pp. 365-388.

McNeely, R., Dyke, A.S., Southon, J.R., 2006. Canadian marine reservoir ages, preliminary data assessment. Open File 5049. Geological Survey of Canada, p. 3.

McNeil, D.H., Duk-Rodkin, A., Dixon, J., Dietrich, J.R., White, J.M., Miller, K.G., Issler, D.R., 2001. Sequence stratigraphy, biotic change, ${ }^{87} \mathrm{Sr} /{ }^{86} \mathrm{Sr}$ record, paleoclimatic history, and sedimentation rate change across a regional late Cenozoic unconformity in Arctic Canada. Can. J. Earth Sci. 38 (2), 309-331. doi:10.1139/cjes-38-2-309.

Miller, E.L., Grantz, A., Klemperer, S.L., 2002. Tectonic evolution of the Bering Shelf, Chukchi Sea, Arctic Margin and adjacent landmasses. Bolder, Colorado. Geol. Soc. Amer., Spec. Pap. 360, 1-24.

Morozova, L.N., 1985. Late Pleistocene (Sartanian) sea level on the East-Arctic shelves. Geology and Geomorphology of Shelves and Continental Slopes. Nauka, Moscow, pp. 85-88 (in Russian).

Morozova, L.N., Biryukov, V.Yu., Volkova, N.A., Zhindarev, L.A., 1978. Main features of inner Chukchi Sea shelf morphology. Geomorphology and Paleogeography of the Shelf. Nauka, Moscow, pp. 131-134 (in Russian).

Organic Matter of Bottom Sediments from World Ocean Polar Regions. 1990. Leningrad, Nedra, 280 pp. (in Russian).

Pavlidis, Yu.A., Babaev, Yu.M., Ionin, A.S., Vozovik, Yu.I., Dunaev, N.N., 1981. Peculiarity of polar morpholithogenesis on the North-East USSR shelf. Continental and Islands Shelves. Relief and Sediments, pp. 33-96. M., Nauka, (in Russian).

Peters, K.E., Walters, C.C., Moldowan, J.M., 2005. The biomarker guide, Second edition. Biomarkers and Isotopes in the Environment and Human History, vol. 1. Cambridge University Press, p. 471.

Petrov, O.M., 1966. Stratigraphy and mollusk fauna from Chukotka Peninsula Quaternary deposits. GIN RAS Proceedings, vol. 155, p. 252. Moscow, (in Russian).

Phillips, R.L., Reiss, T.E. 1985. Nearshore marine geologic investigations, Point Barrow to Skull Cliff, northeast Chukchi Sea. U.S. Geological Survey Open-file Report 85-50. 22 p.

Phillips, R.L., Colgan, M.W., 1987. Vibracore stratigraphy of the northeastern Chukch Sea. In: Hamilton, T.D., Galloway, J.P. (Eds.), Geological Studies in Alaska by the U.S. Geological Survey during 1986. U.S. Geological Survey Circular 998, pp. 157-160.

Phillips, R.L., Barnes, P., Hunter, R.E., Reiss, T.E., Rearik, D.M. 1988a. Geological investigations in the Chukchi Sea, 1984, NOAA ship Surveyor cruise. U.S. Geological Survey Open-file Report 88-25. 82 pp.

Phillips, R.L., Pickthorn, L.G., Rearic, D.M., 1988b. Late Cretaceous sediments from the northeast Chukchi Sea. In: Galloway, J.P., Hamilton, T.D. (Eds.), Geological Studies in Alaska by U.S. Geological Survey during 1987. U.S. Geological Survey Circular 1016, pp. 187-189.

Polyak, L., Levitan, M., Khusid, T., Merklin, L., Mukhina, V., 2002. Variations in the influence of riverine discharge on the Kara Sea during the last deglaciation and the Holocene. Global Planet. Change 32, 291-309.

Polyakova, Ye.I., 1989a. Stratigraphy of Chukchi Sea bottom sediments and its paleogeography (diatom analyses). Geology of Continental Shelf of Marginal and Interior Seas, pp. 136-148. Moscow, (in Russian).
Polyakova, Ye.I., 1989b. Late Pleistocene-Holocene sediments stratigraphy of the Beringian shelf by diatom assemblages. Norway a review. Boreas 8 (2), 247-253.

Polyakova, Ye.I., 1989c. Diatoms in the Arctic shallow seas sediments. In: Herman, Y. (Ed.), The Arctic Seas (Climatology, Oceanography, Geology and Biology), pp. 481-496. New York.

Polyakova, Ye.I. 1997. The Eurasian Arctic Seas during the Late Cenozoic. M.: Scientific World, 142 pp. (in Russian).

Polyakova, Ye.I., 1999. Holocene diatom stratigraphy and paleoceanography of the Eurasian Arctic Seas. In: Kassens, H., Bauch, H.A., Eicken, H., Hubberten, H.W., Melles, M., Thiede, J., Timokhov, L. (Eds.), Land-Ocean Systems in the Siberian Arctic: Dynamics and History. Springer-Verlag, Berlin, pp. 615-634.

Puminov, A.P., 1981. Stratigraphy of Cenozoic sediments of East Russian Arctic Shelf. Geology and Mineralogy of the Arctic Part of USSR, pp. 7-27 (in Russian).

Radi, T., de Vernal, A., 2004. Dinocyst distribution in surface sediments from the northeastern Pacific margin $\left(40-60^{\circ} \mathrm{N}\right)$ in relation to hydrographic conditions, productivity and upwelling. Rev. Palaeobot. Palynol. 128 (1), 169-193. doi:10.1016/ S0034-6667(03)00118-0.

Radi, T., de Vernal, A., Peyron, O., 2001. Relationships between dinoflagellate cyst assemblages in surface sediment and hydrographic conditions in the Bering and Chukchi seas. J. Quat. Sci. 16 (7), 667-680.

Rex, R.W., 1955. Microrelief produced be sea ice grounding in the Chukchi Sea near Barrow, Alaska. Arctic 8, 177-186.

Romankevich, E.A., Vetrov, A.A., 2001. Carbon Cycle in Russian Arctic Seas. Nauka, Moscow. 302 pp. (in Russian).

Saidova, H.M., 1994. Ecology of the shelf foraminifers communities and Holocene paleoenvironments in Bering and Chukchi seas. Nauka, Moscow. 95 pp. (in Russian).

Saliot, A., Laureillard, J., Scribe, P., Sicre, M.A., 1991. Evolutionary trends in the lipid biomarker approach for investigating the biogeochemistry of organic matter in the marine environment. Mar. Chem. 36 (1), 233-248.

Sohlenius, G., 1996. Mineral magnetic properties of Late Weichselian-Holocene sediments from the northwestern Baltic Proper. Boreas 25, 79-88.

State Geological Map of Russian Federation. Sheet S-1,2 (Chukchi Sea). Scale 1:1000 000. St. Petersburg. Map factory VSEGEI. 2006 (in Russian).

Stein, R., Dittmers, K., Fahl, K., Kraus, M., Matthiessen, J., Niessen, F., Pirrung, M., Polyakova, Ye., Schoster, F., Steinke, T., Futterer, D.K., 2004. Arctic (paleo) river discharge and environmental change: evidence from the Holocene Kara Sea sedimentary record. Quat. Sci. Rev. 23 (11-13), 1485-1511. doi:10.1016/j.quascirev.2003.12.004.

Stepanova, G.B., 1990. Diatom complexes from Taymyr Peninsula and its significant for Cenozoic stratigraphic scheme. Stratigraphy and Paleontology of Soviet Arctic Mesozoic and Cenozoic. L. Sevmorgeologia, pp. 59-73 (in Russian).

Svitoch, A.A., Taldenkova, E.E., 1994. Recent history of the Bering Strait. Oceanology 34, 400-404 (in Russian)

Thurston, D.K., Theiss, L.A., 1987. Geologic Report for the Chukchi Sea Planning Area, Alaska. U.S. Department of the Interior Minerals Management Service, Anchorage, Alaska.

Vartanyan, S.L., Arslanov, Kh.A., Tertychnaya, T.V., Chernov, S.B., 1995. Radiocarbon dating evidence for mammoths on Wrangel Island, Arctic Ocean, until 2000 BC. Radiocarbon 37 (1), 1-6.

Venkatesan, M., 1988. Occurrence and possible sources of perylene in marine sediments. Mar. Chem. 25 (1), 1-27.

Venkatesan, M., Kaplan, I., 1982. Distribution and transport of hydrocarbons in surface sediments of the Alaskan Outer Continental Shelf. Geochim. Cosmochim. Acta 46 (11), 2135-2149.

Venkatesan, M., Ruth, E., Steinberg, S., Kaplan, I., 1987. Organic geochemistry of sediments from the continental margin off southern New England, USA. Part.2, Lipids. Mar. Chem. 21 (3), 267-299.

Vinogradov, V.A., Gusev, E.A., Lopatin, B.G. 2006. Structure of the Russian Eastern Arctic Shelf. In: Scott, R.A., Thurston, D.K. (Eds.), Proceedings of the Fourth International Conference on Arctic Margins, OCS study MMS 2006-003. U.S. Department of the Interior, pp. 90-98.

Yanagisawa, Y., Akiba, F., 1998. Refined Neogene diatom biostratigraphy for the northwest Pacific around Japan, with an introduction of code numbers for selected diatom biohorizons. J. Geol. Soc. Japan 104, 395-414.

Yunker, M.B., Macdonald, R.W., Cretney, W.J., Fowler, B.R., McLaughlin, F.A., 1993. Alkanee, terpene and polycyclyc aromatic hydrocarbon geochemistry of the Mackenzie River and Mackenzie shelf: riverine contributions to Beaufort Sea coastal sediment. Geochim. Cosmochim. Acta 57, 3041-3061.

Zhuze, A.P., 1962. Stratigraphic and Paleogeographic Investigations in the Northwestern Part of Pacific Ocean. Moscow, 259 pp. (in Russian).

Zhuze, A.P., 1969. Diatoms in Pleistocene and Late Pliocene in boreal sediments from Pacific Ocean. Main Problems in Micropaleontology and Biogenic Sedimentation in Oceans and Seas. Nauka, Moscow, pp. 5-27 (in Russian). 